\title{
دور البصمة الوراثية في حماية الأنساب
}

Doi: $10.23918 /$ ilic2021.29

\section{هتهوت فاطنة}

طالبة الدكتوراه

hathoutfa2003@gmail.com

المخبر المتوسطي للاراسات القانونية

كلية الحقق و العلوم السياسية- جامعة تلمسان.

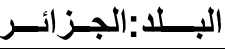

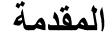

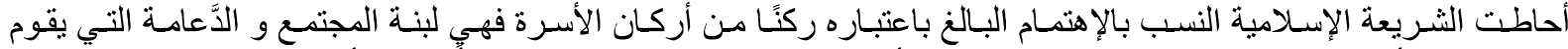

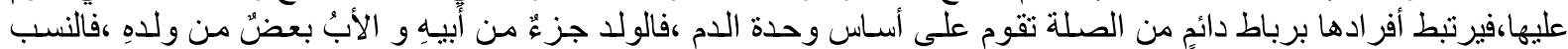

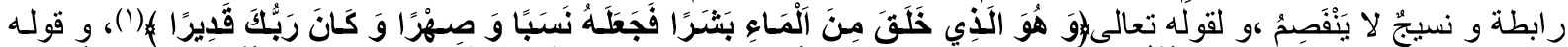

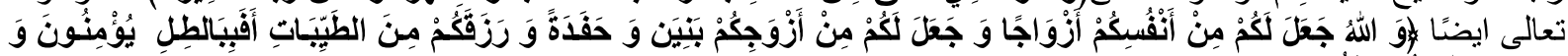

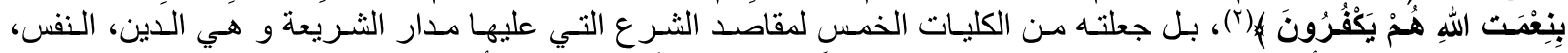

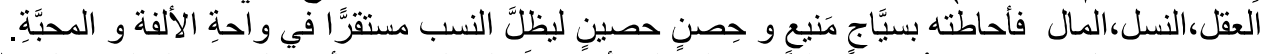

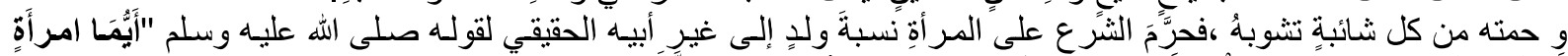

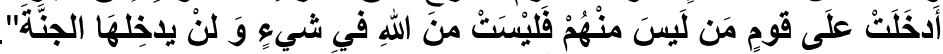

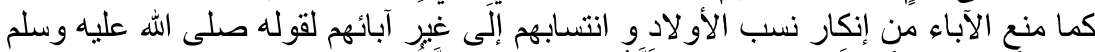

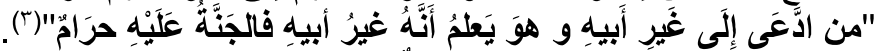

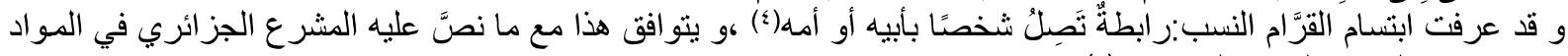

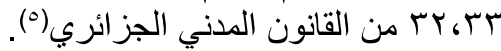

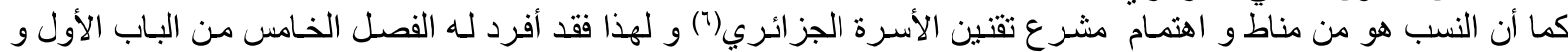

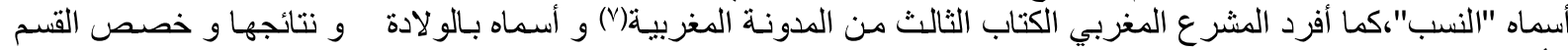

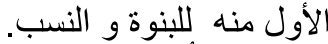

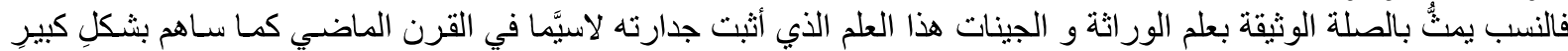

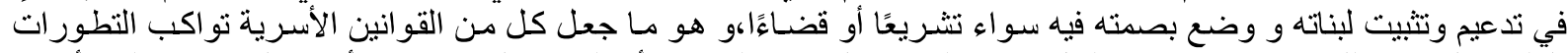

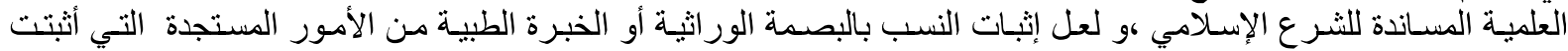

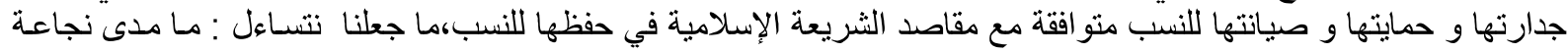

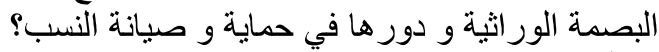

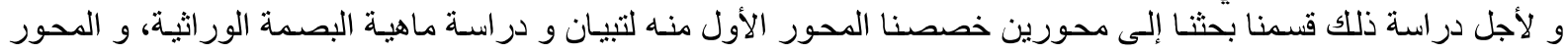

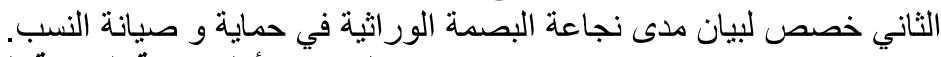
المحور الأول:ماهية البصمة البهائة الوراثية

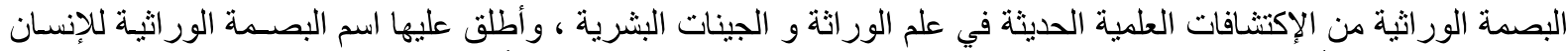

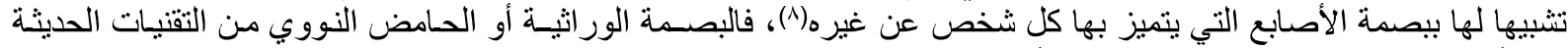

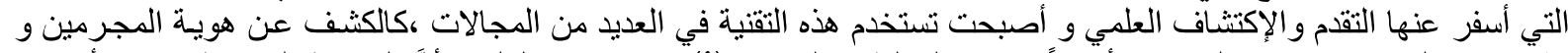

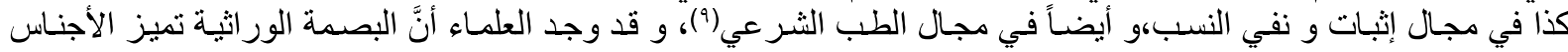

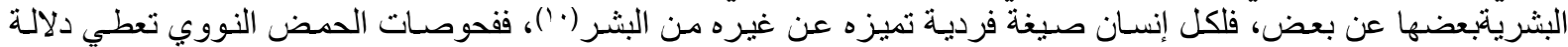

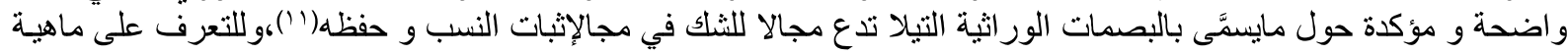

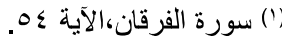

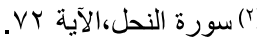

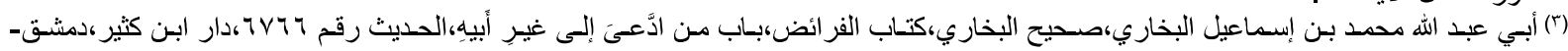

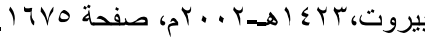

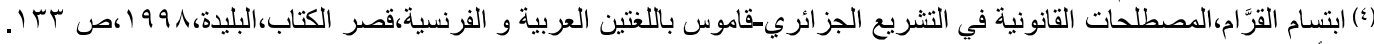

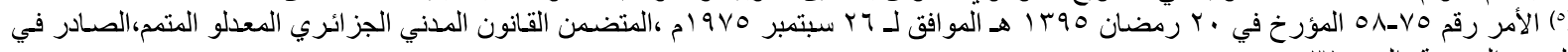

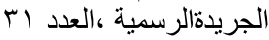

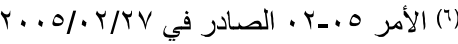

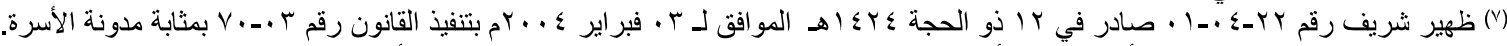

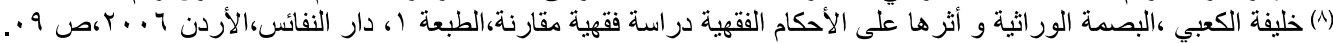

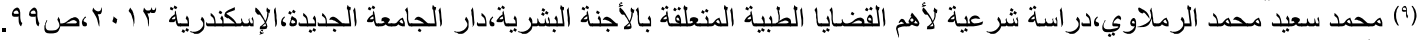

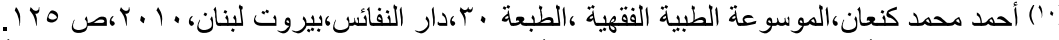

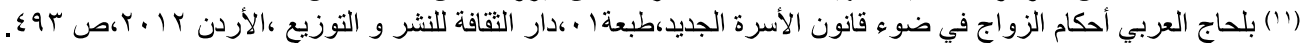


البصمة الور اثية قسمنا هذا المحور إلى مبحثين خصصنا الأول منه لدراسة مفهوم البصمة الور اثية أمـا الثاني فخصصناه لدراسـة

المبحث الأول :مفهوم البصمة الوراثية

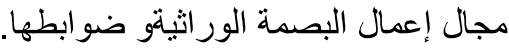

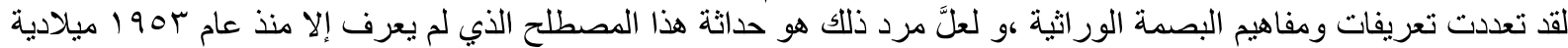

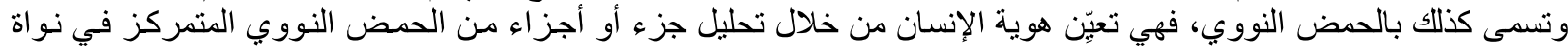

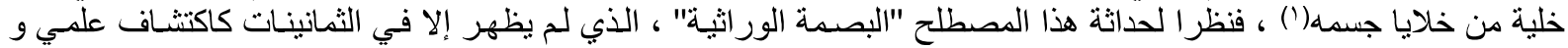

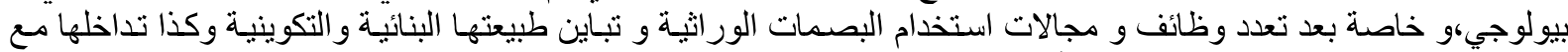

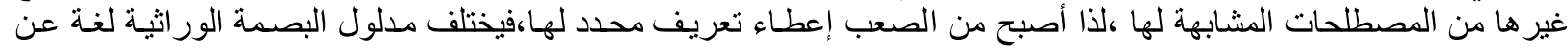

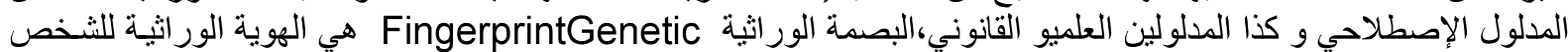

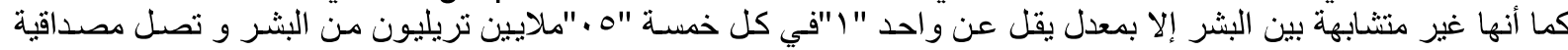

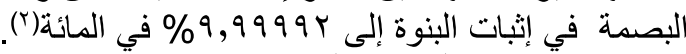

أولا: تعريف البصمة الوراثية:

يختلف تعريف البصمة الور اثية لغة عنة التهة التعريف الإصطلاحي و العلمي و كذا القانوني و هذا ما سنحاول تبيانسه من خلال هذا المطلب

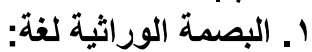

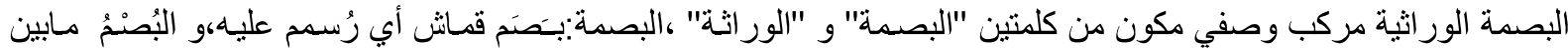

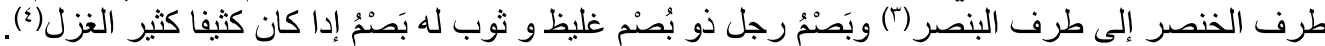

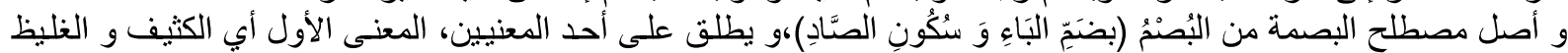

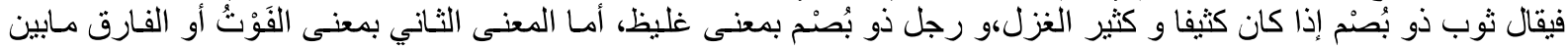

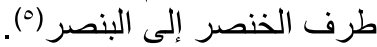

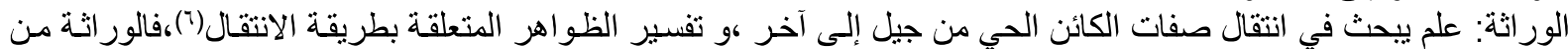

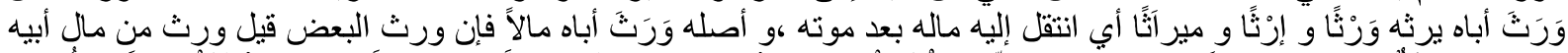

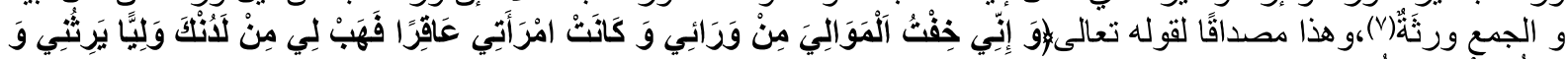

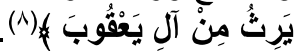

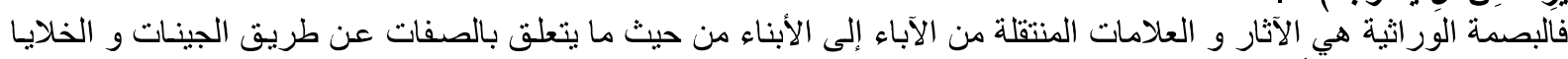

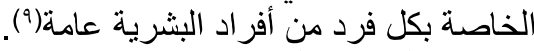

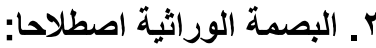

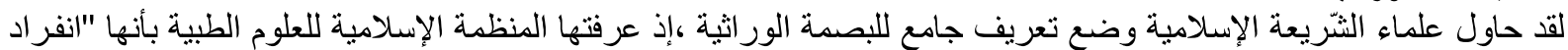

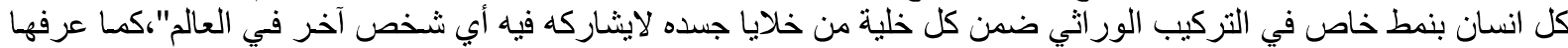

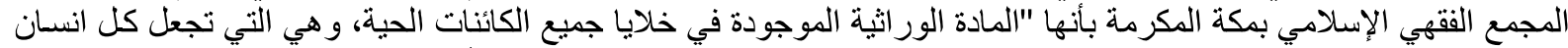

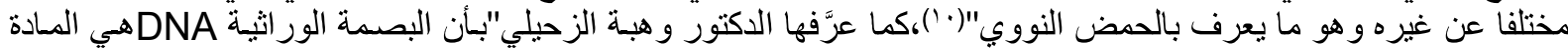

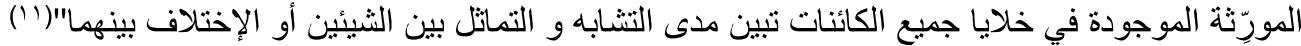

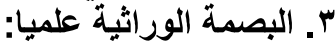

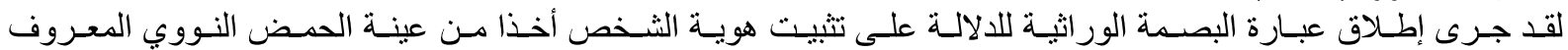

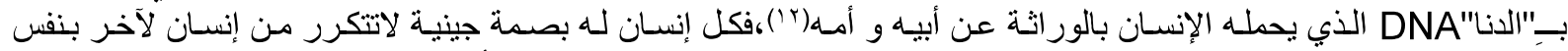

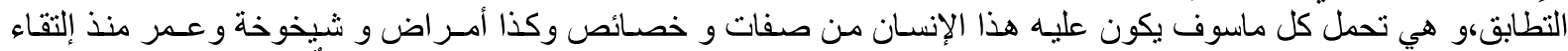

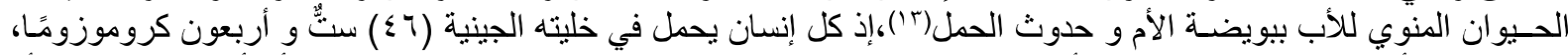

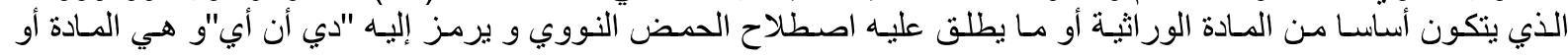

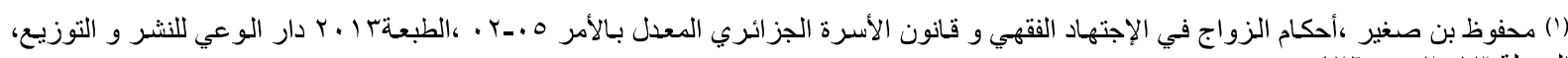

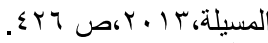

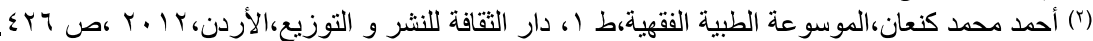

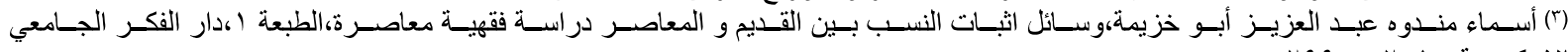

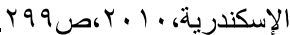

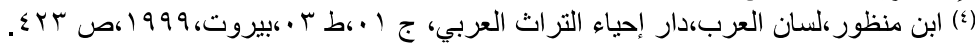

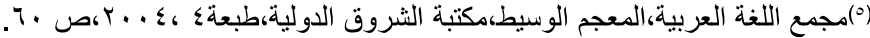

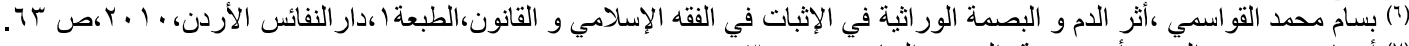

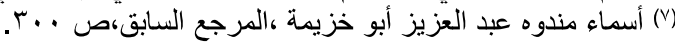

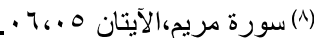

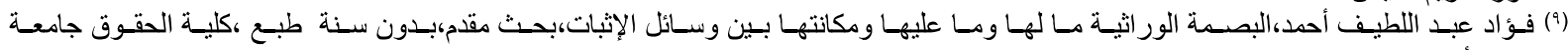

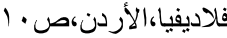

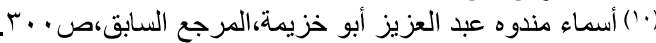

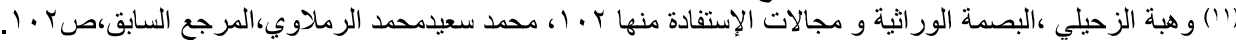

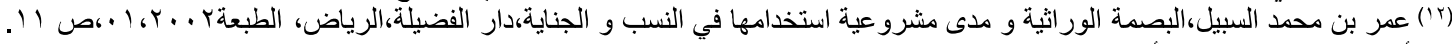

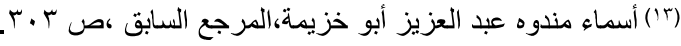




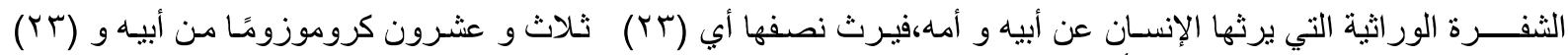

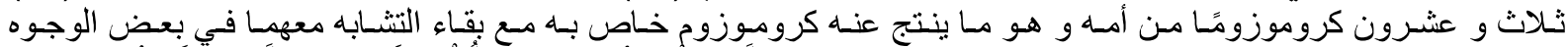

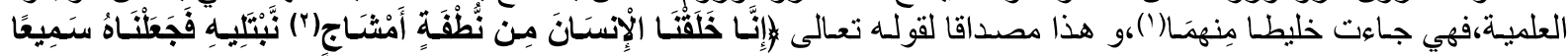

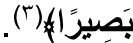

ع ـ البصمة الوراثية قاتونا:

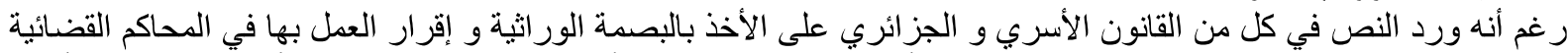

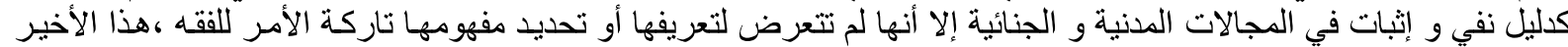

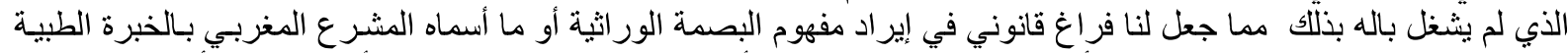

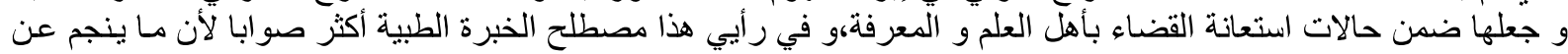

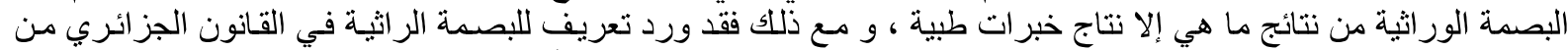

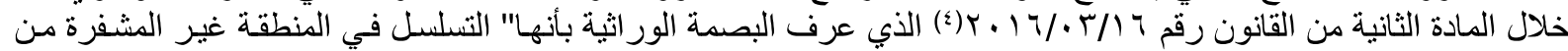

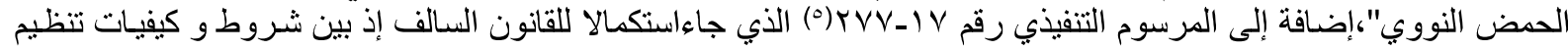

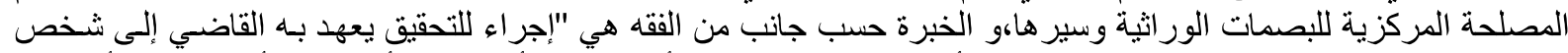

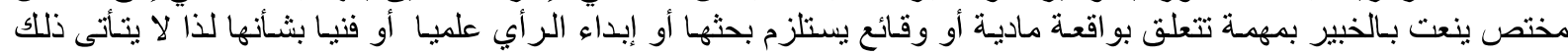

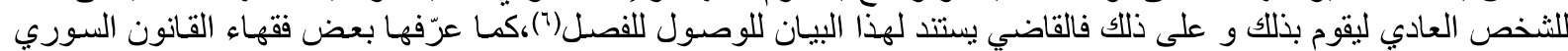

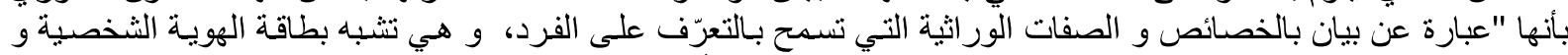

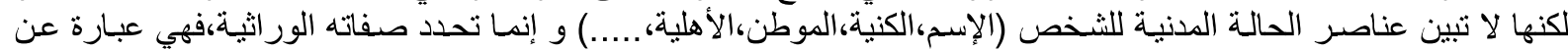

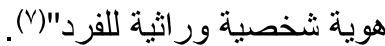
ثانيا :مصادر البصمة الورزية الثية و خصائصها:

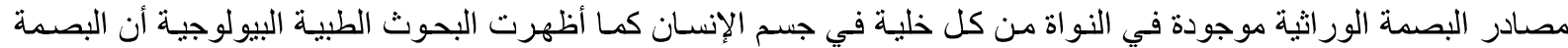

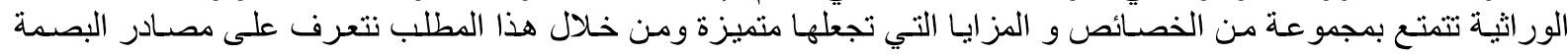

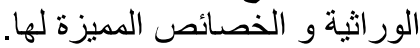

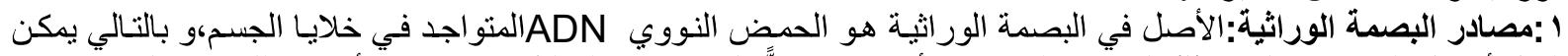

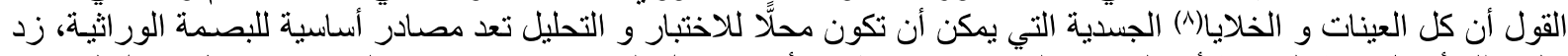

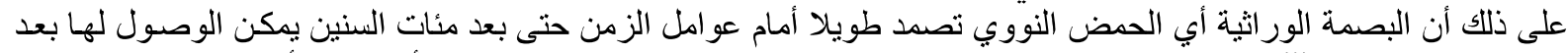

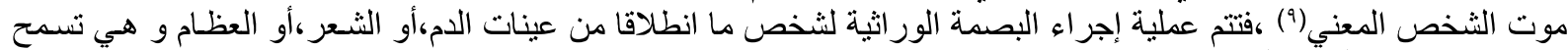

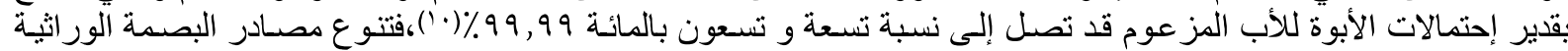

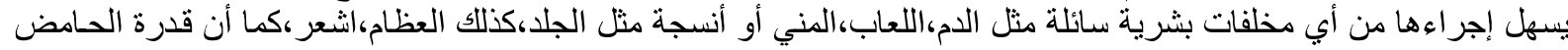

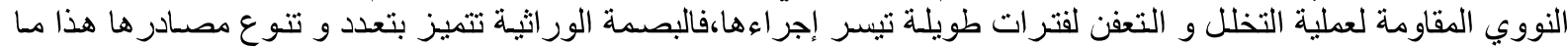

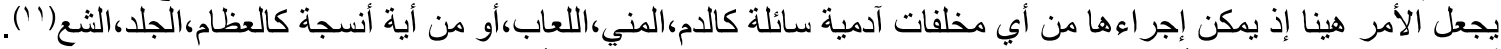

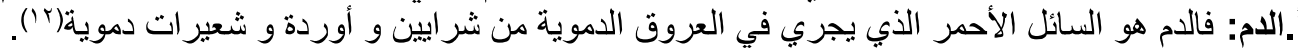

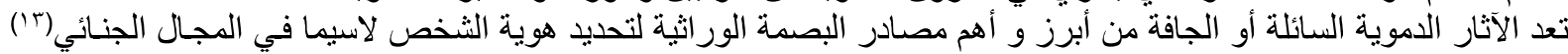

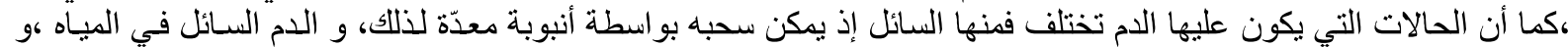

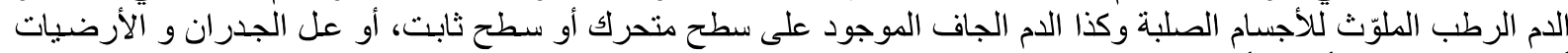

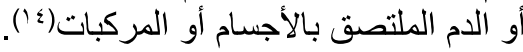

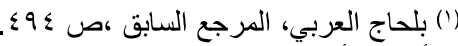

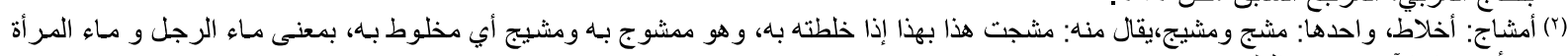
يمشج أحدهما بالآخر ،تفسير الطبري.

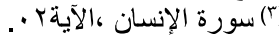

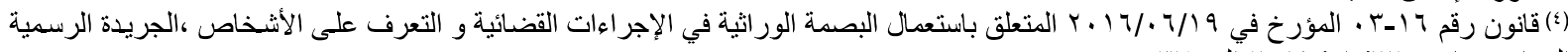

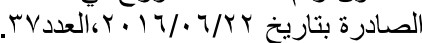

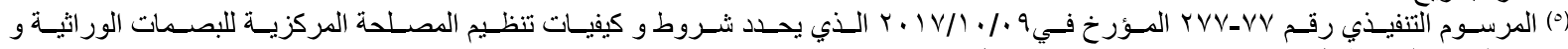

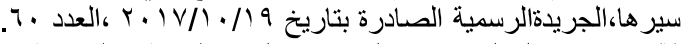

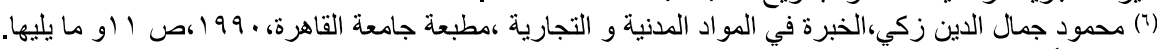

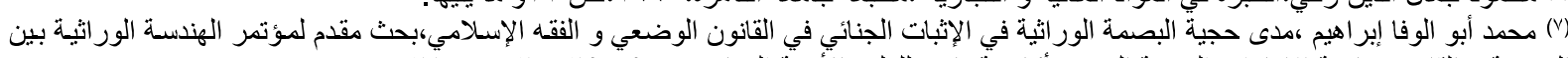

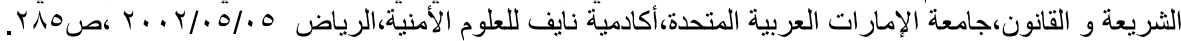

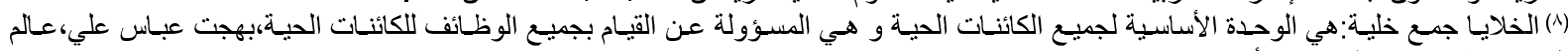

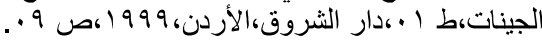

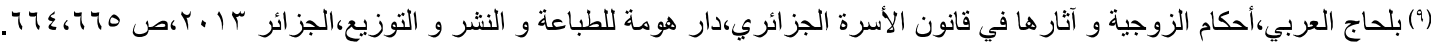

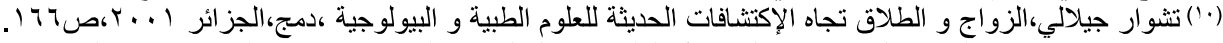

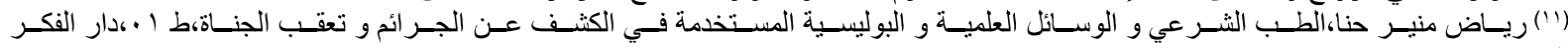

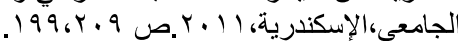

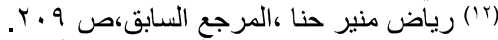

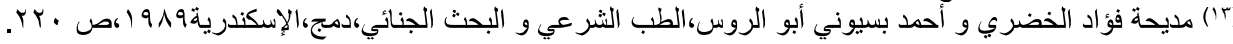

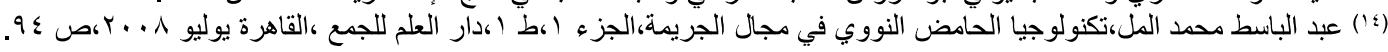




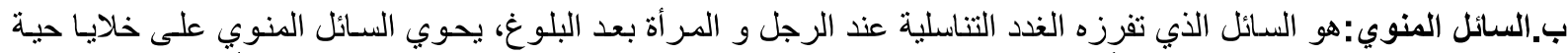

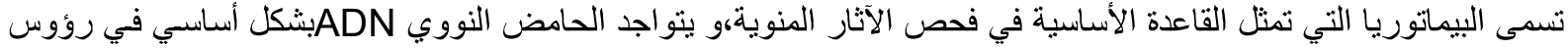

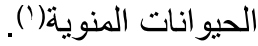

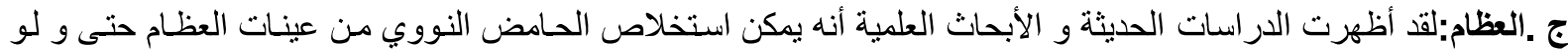

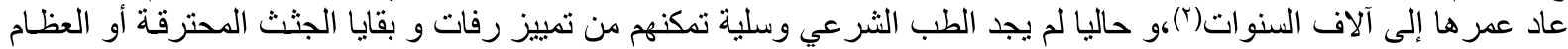

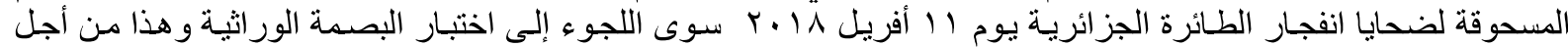
الكثف عن هوية الضحايا. د.الأسنان: فقد ثبت أنه بالإمكان استخلاص الحمض النوان النووي من الأسنان أنه أكثر نجاعة من المواد المتعفنة و المتحللة ،فالأسنان

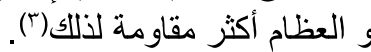

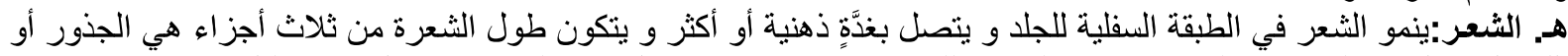

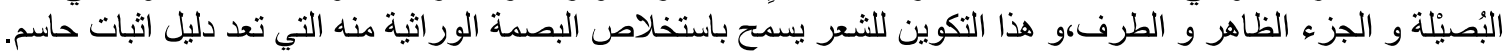

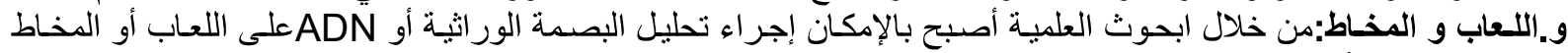

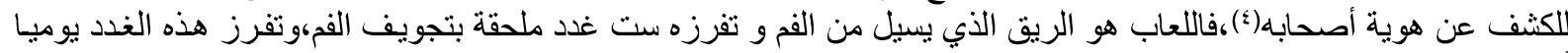

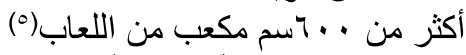

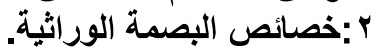

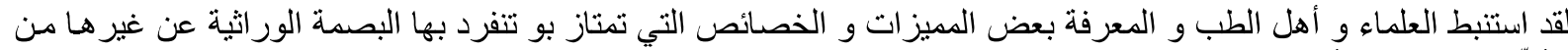

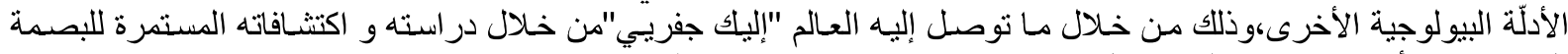

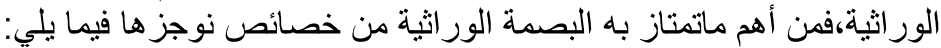

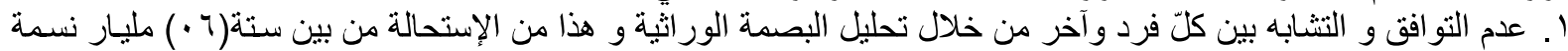

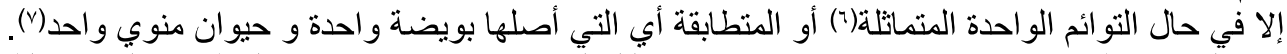

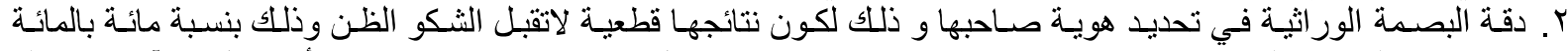

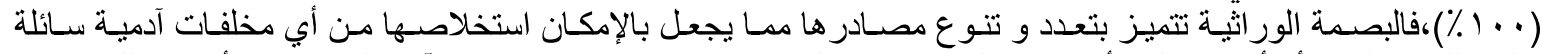

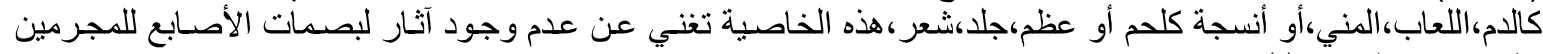

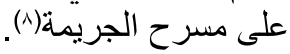

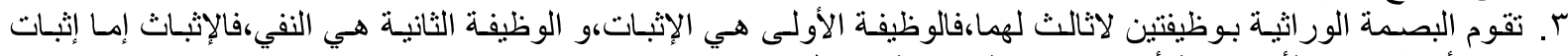

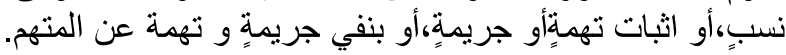

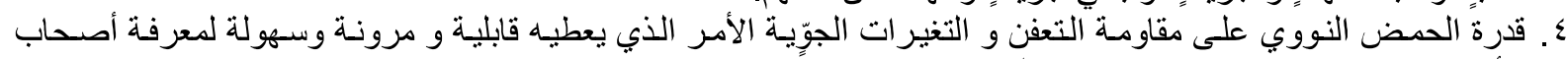

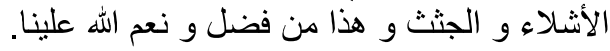

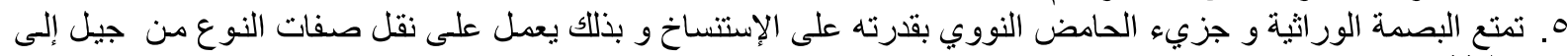
المبحث الثاني: مجال استخدام البصمة الوراثية في النسب

أولا. مكانة النسب في الشريعة الإسلامية.

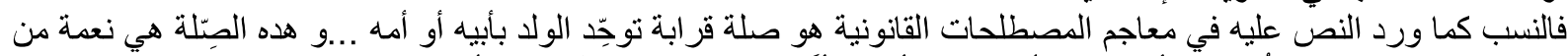

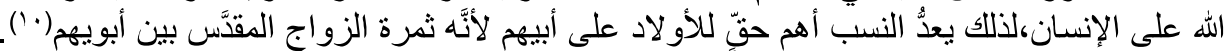

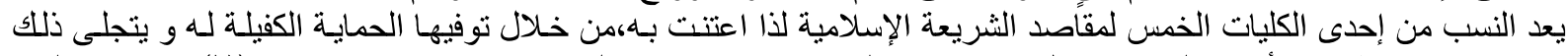

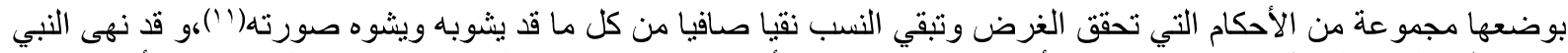

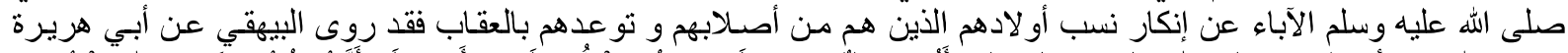

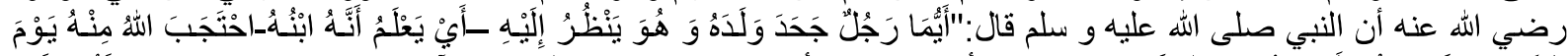

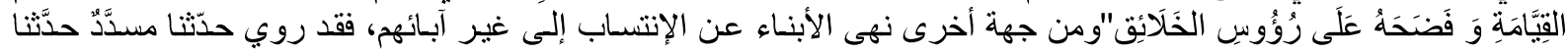

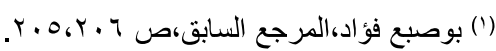

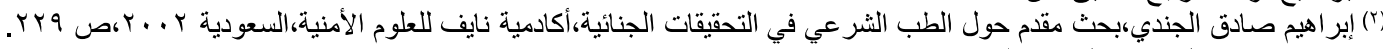

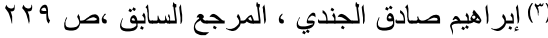

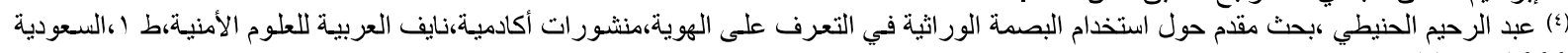
11 (1) 1999

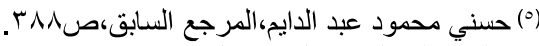

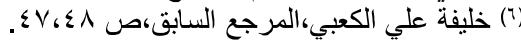

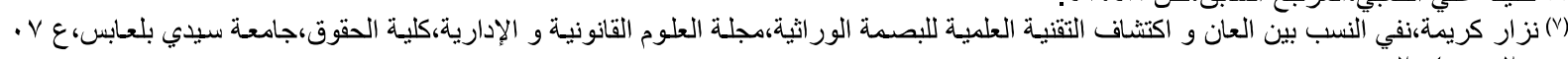

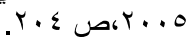

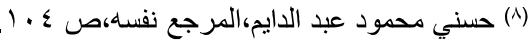

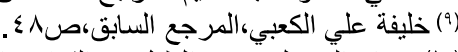

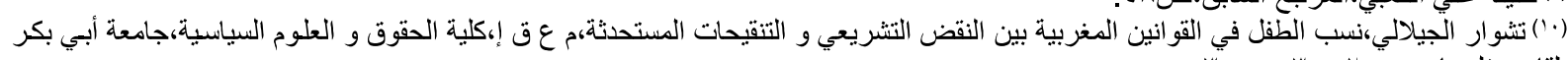

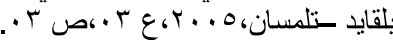

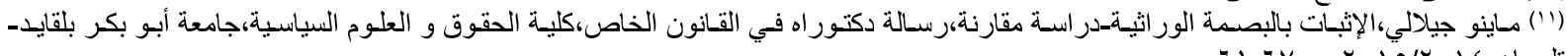

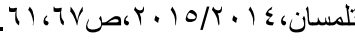




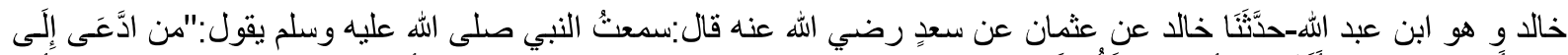

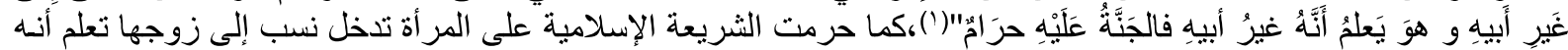

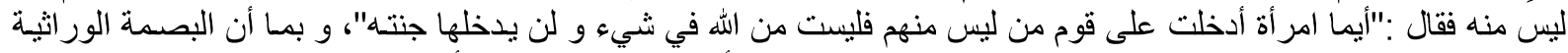

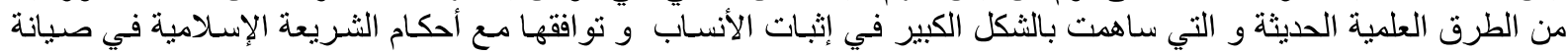

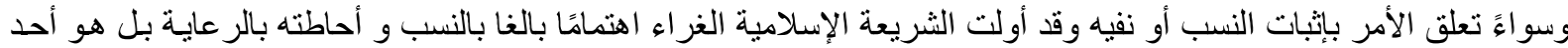

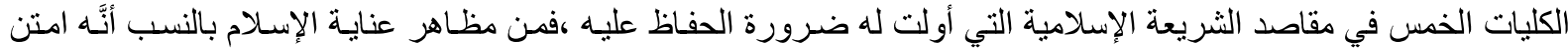

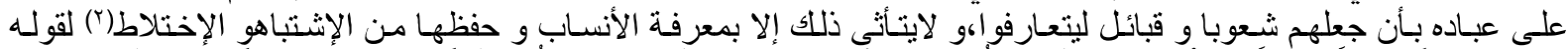

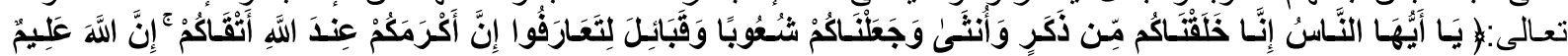

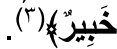

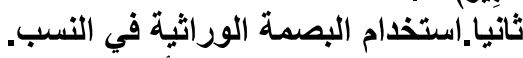

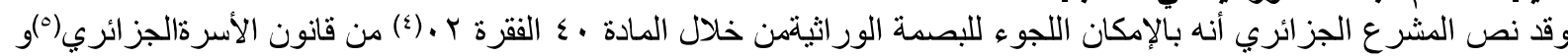

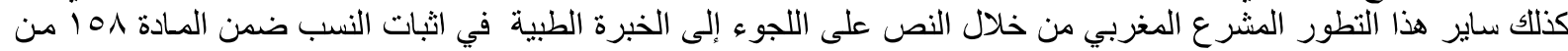

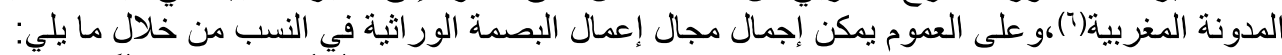

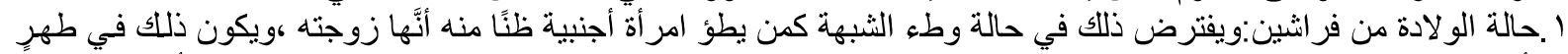

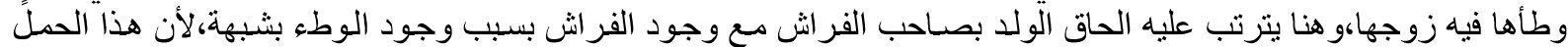

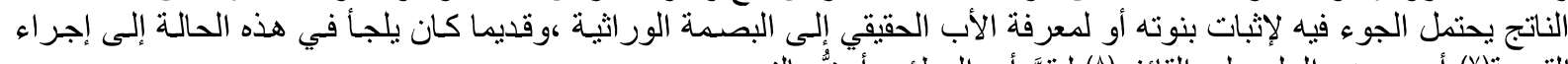

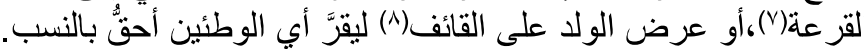

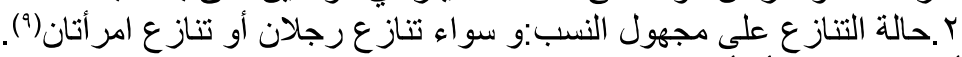

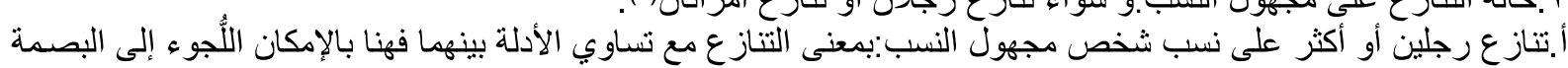

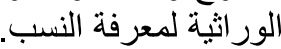

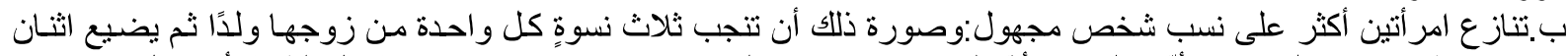

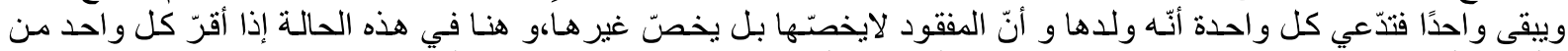

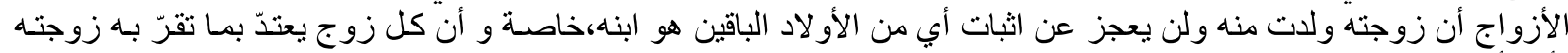

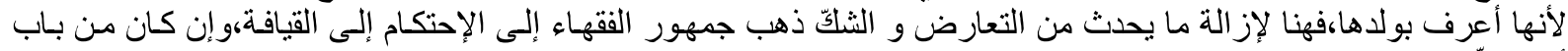

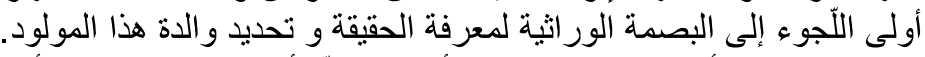

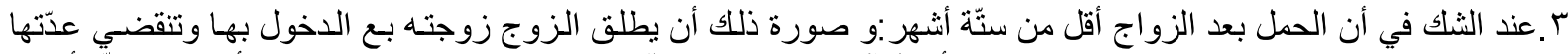

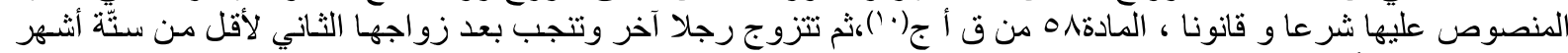

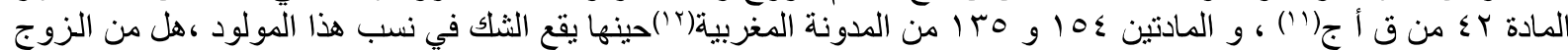

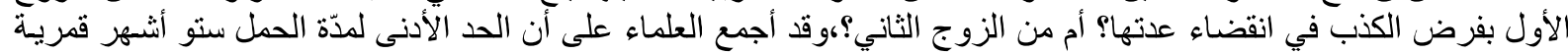

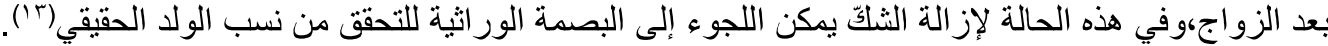

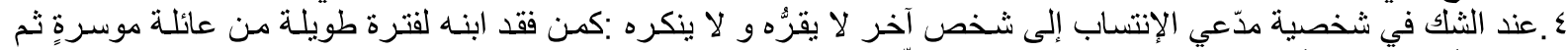

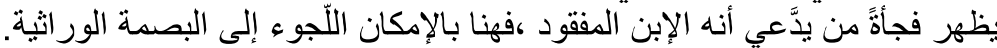

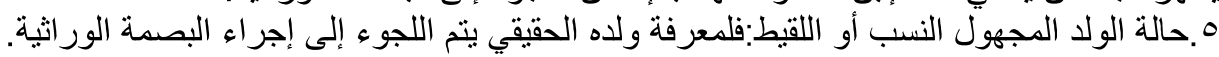

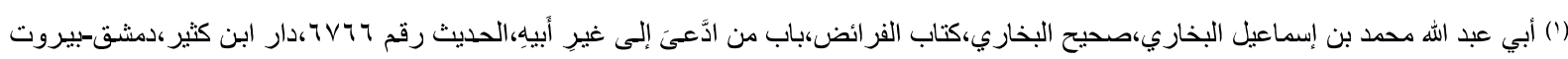

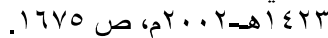

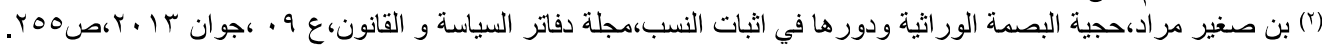

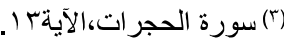

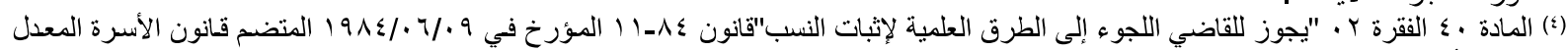

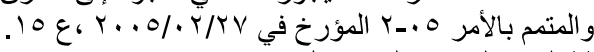
(1)

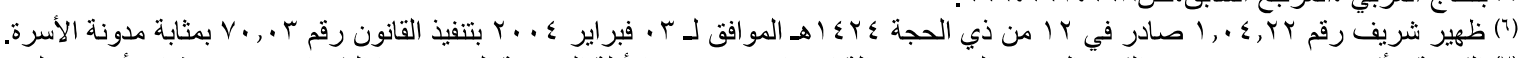

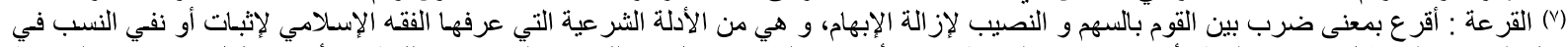

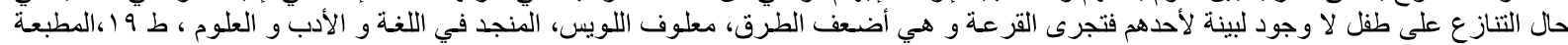

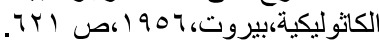

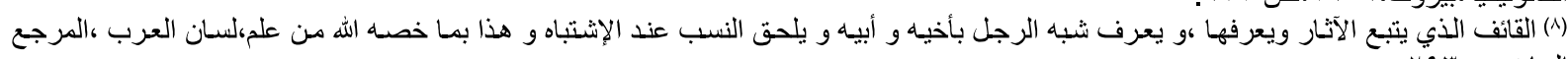

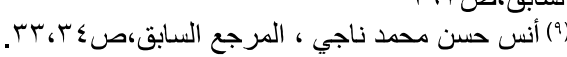

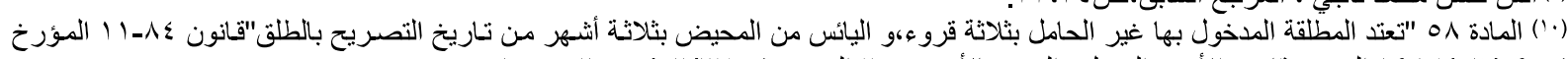

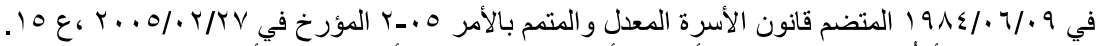

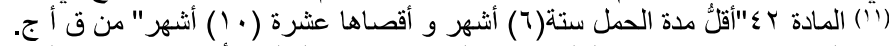

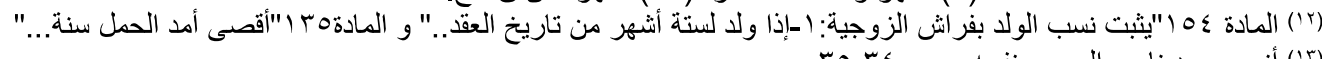

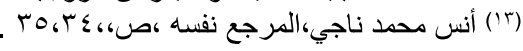




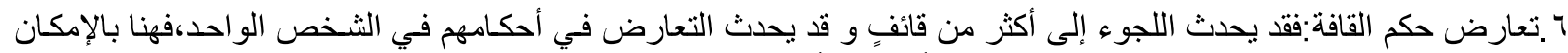

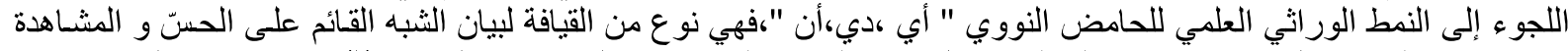

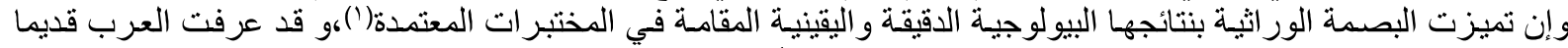

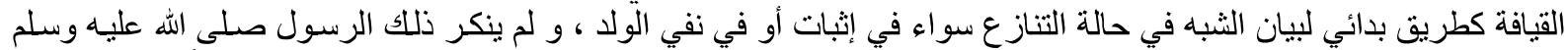

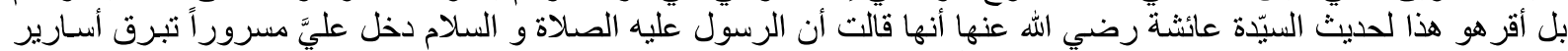

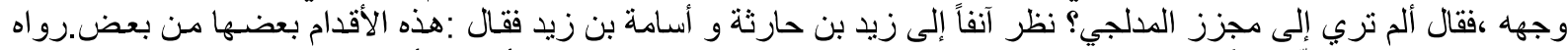

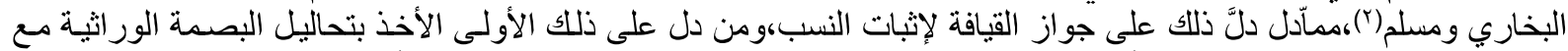

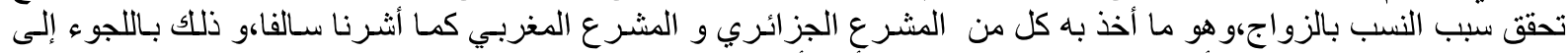

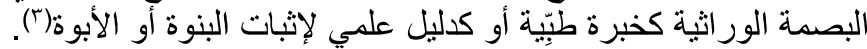

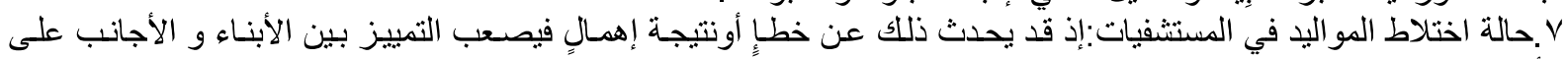

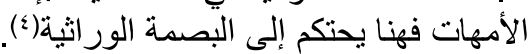

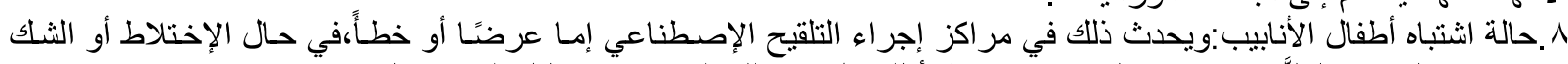

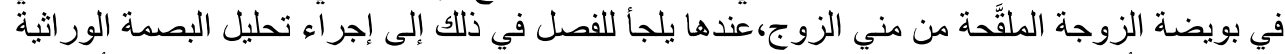

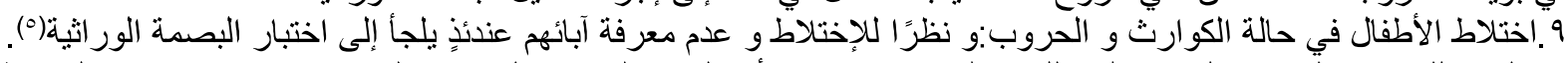

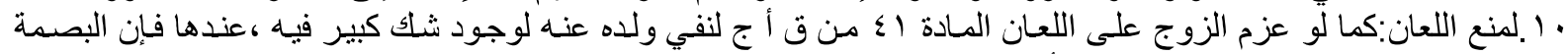

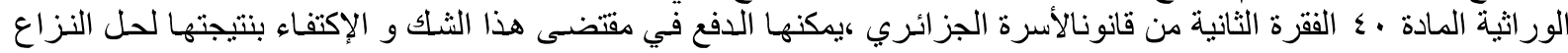

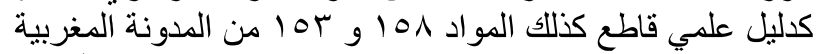

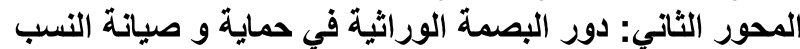

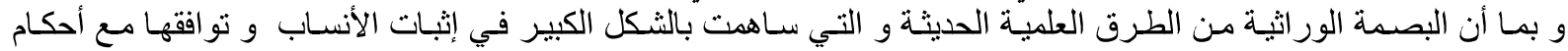

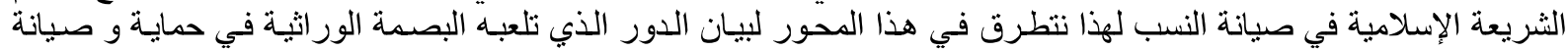

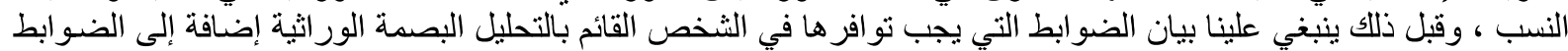

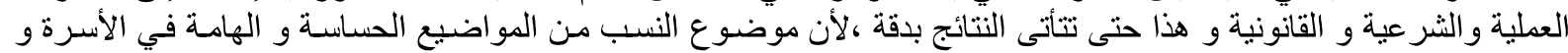

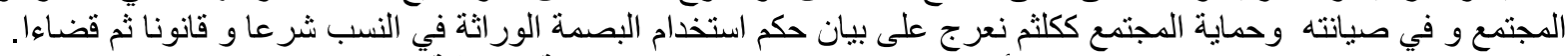

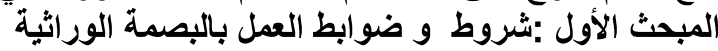

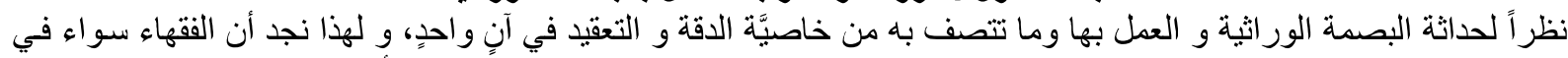

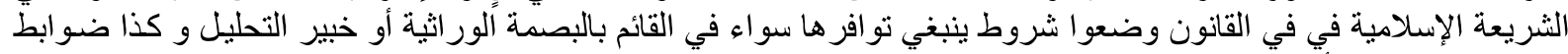
شر عية و قانونية و أخرى عيد فيلية.

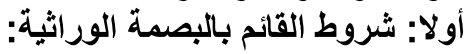

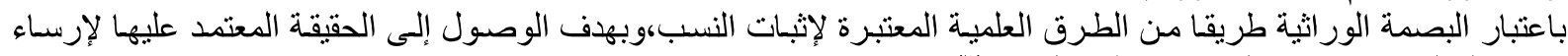

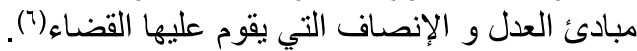

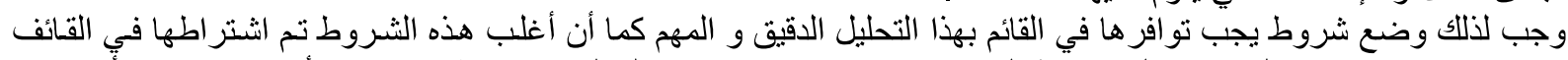

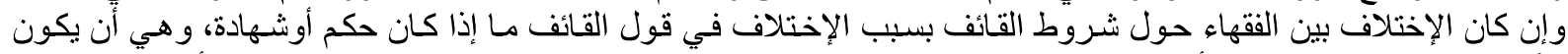

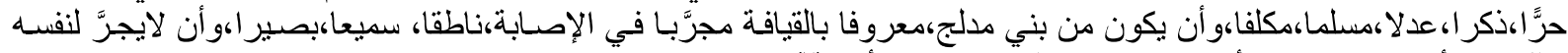

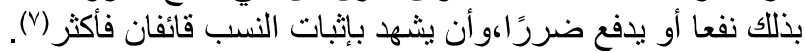

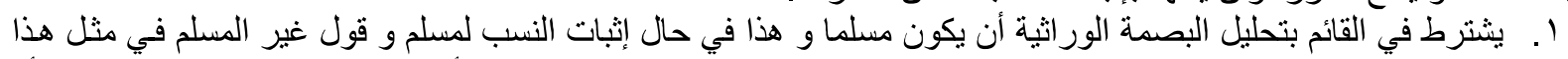

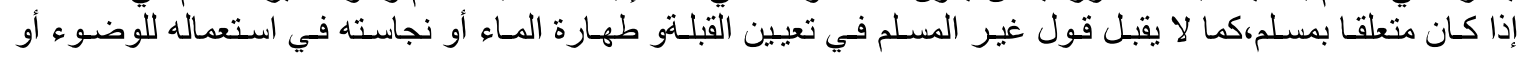

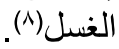
r. العدالة ،لأن الهوى في هذا المقام يحمل على قول غير الحق طمعا في المال أو لغير ذلك من الأسباب،إضـافة إلى الخبرة و

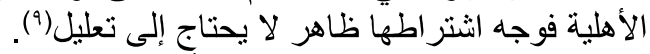

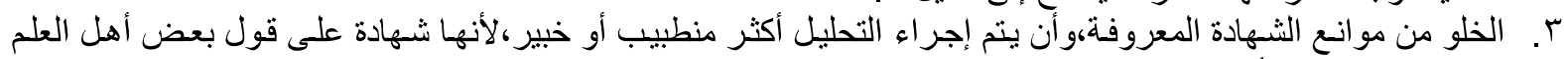
و لايقبل في الحقوق أقل من شاهدين.

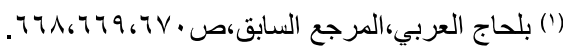

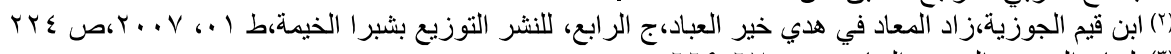

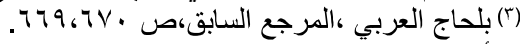

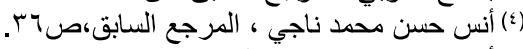

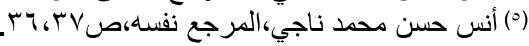

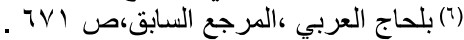

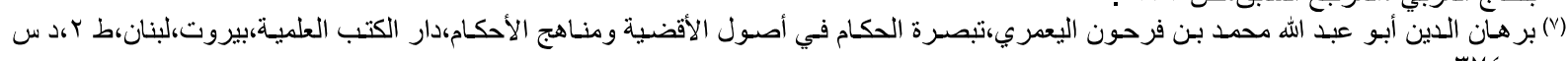

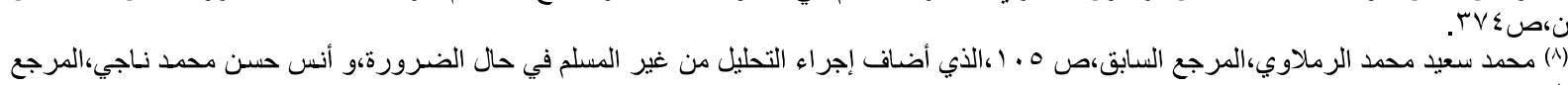

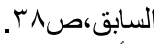

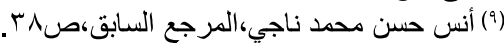


ع. أن يتم إجراء التحليل بناءا على أوامر القضاء أو من له سلطة ولي الأمر و هذا لتفادي التلاعب و اتِبّاع الأهواء الظنيّة عند ضعاف النفوس('). (النيل

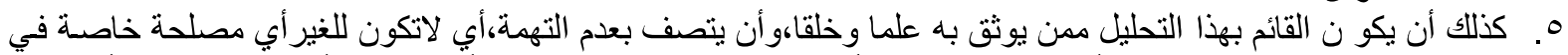

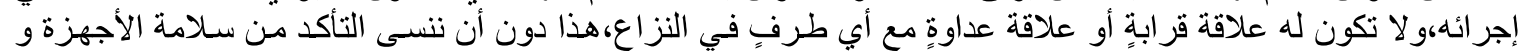

ثانيا: الضوابط الثرعية و القانونية:

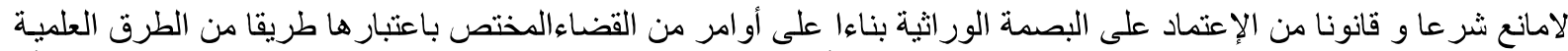

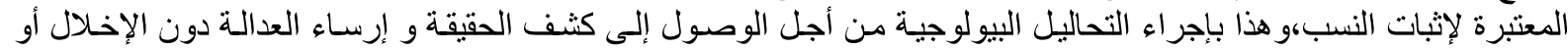

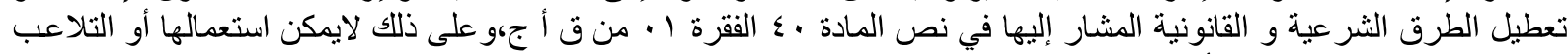

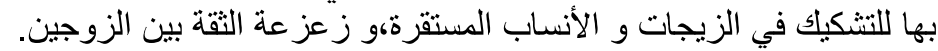

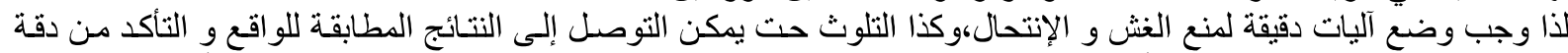

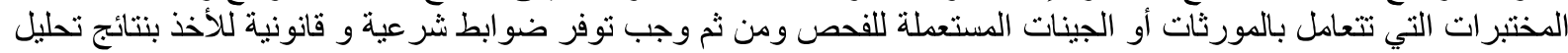

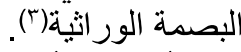

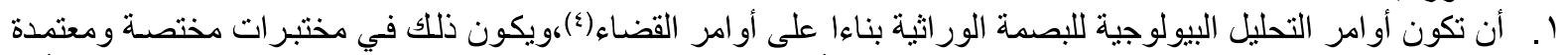

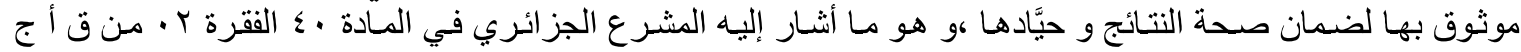

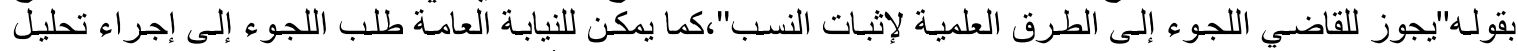

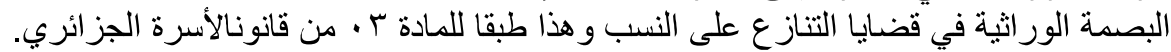

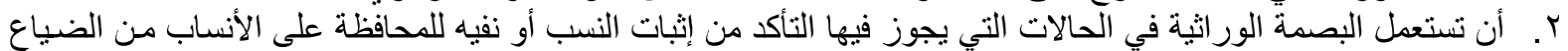

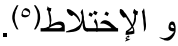

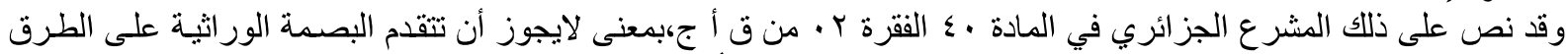

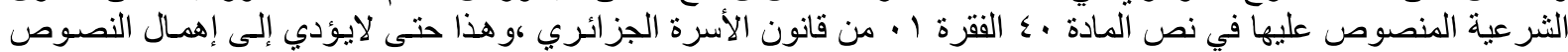
الثرعية و القانونية في ذللك.

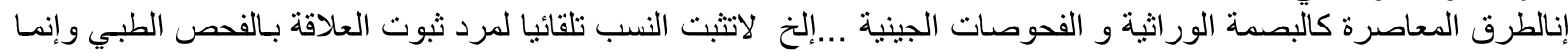

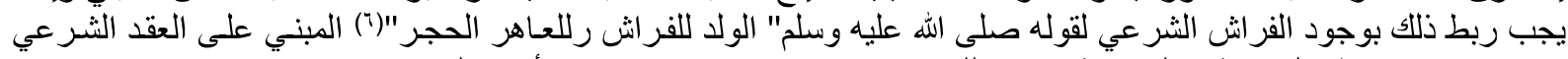

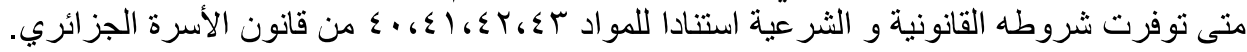

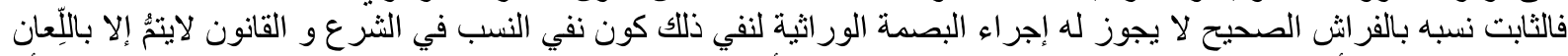

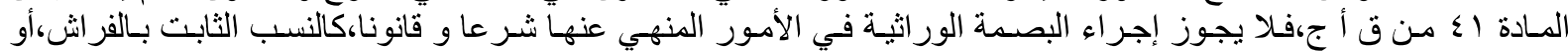

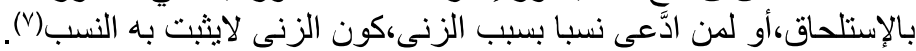

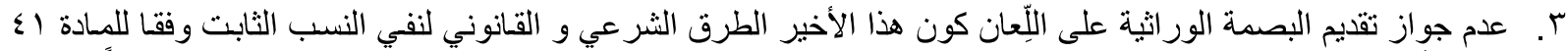

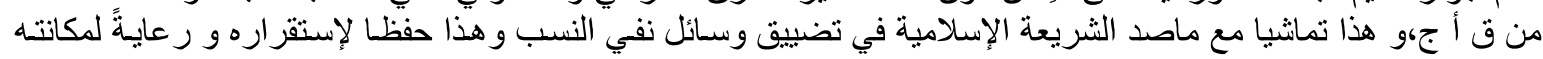

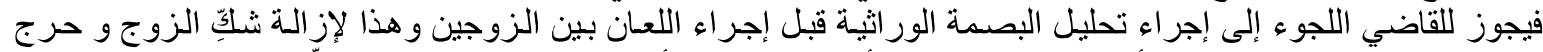

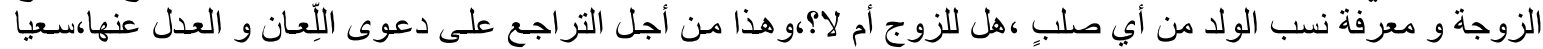

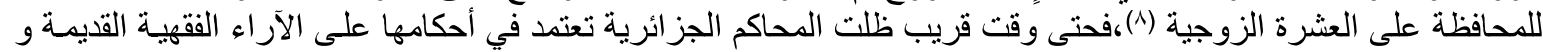

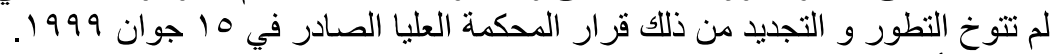

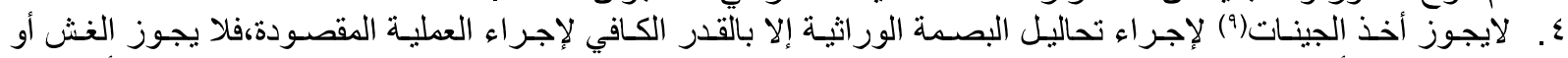

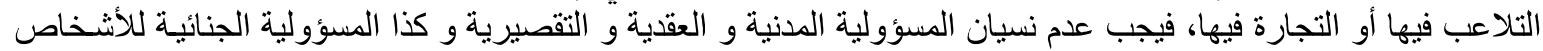

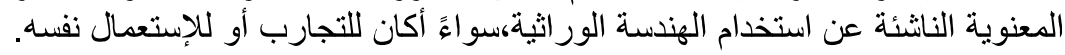

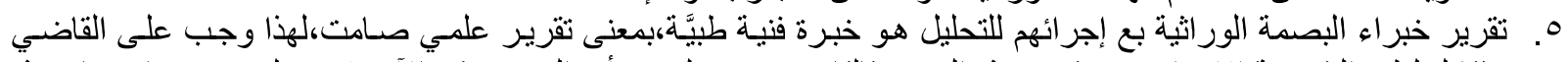

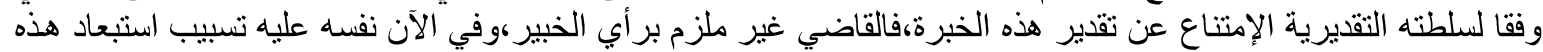

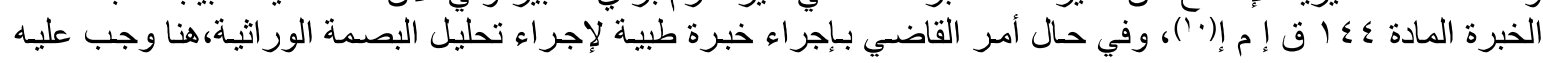

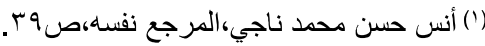

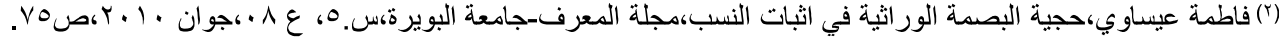

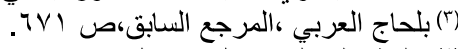

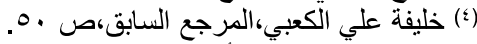

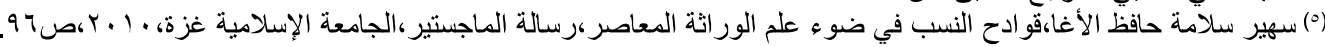

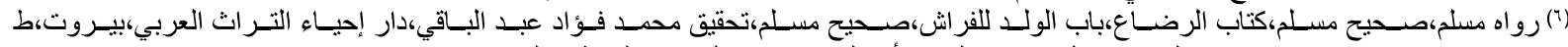

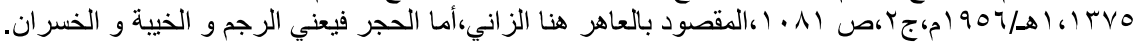

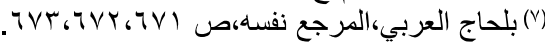

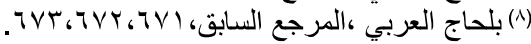

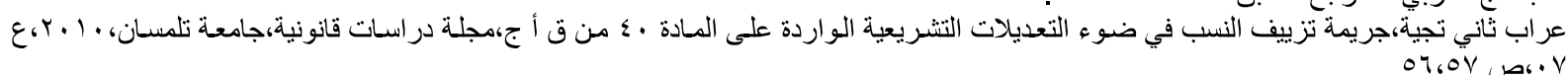

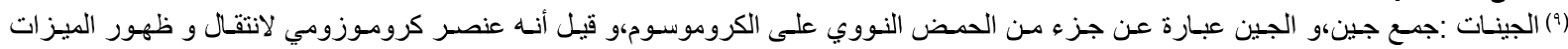

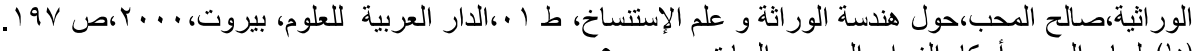

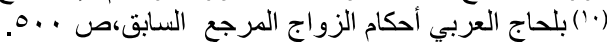




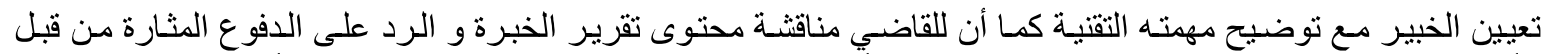

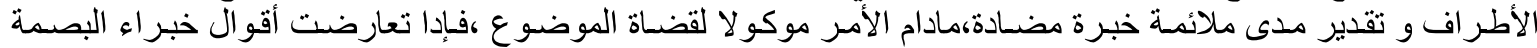

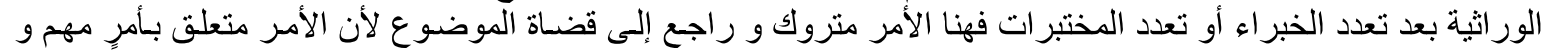

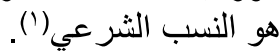

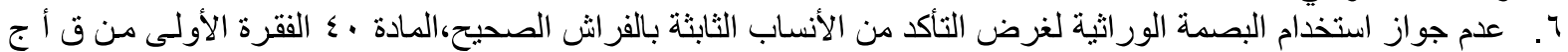

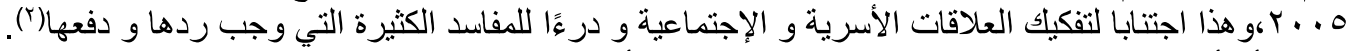

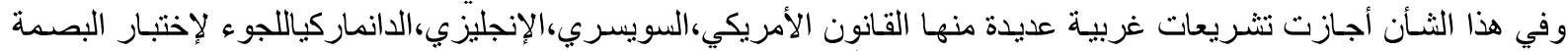

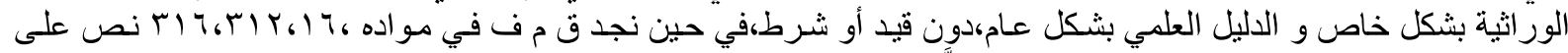

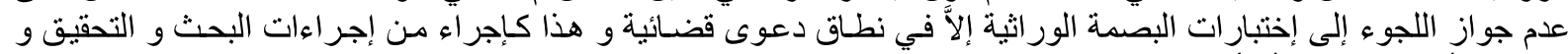

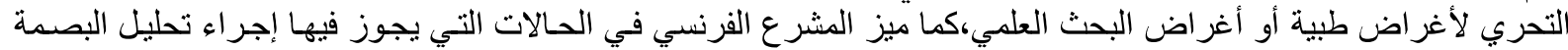

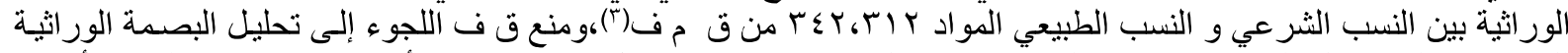

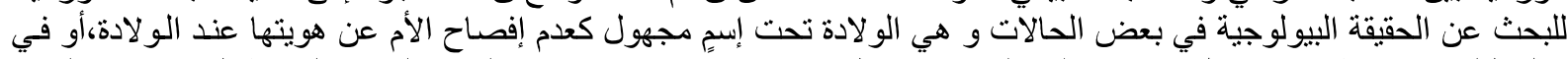

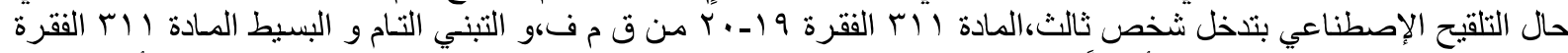

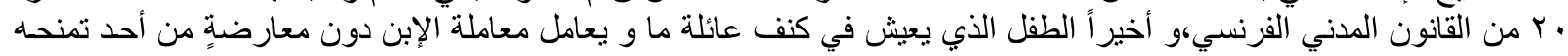

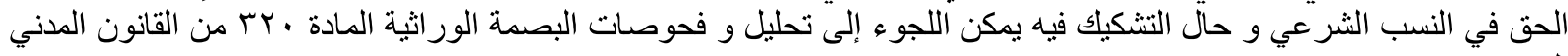

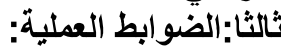

فإجراء تحليل البصمة الوراثية الثية لابد أن يحاط بضوابط عملية تكمل الضوابط القانونية و الثرعية إضافة للشروط الواجب تو افرها

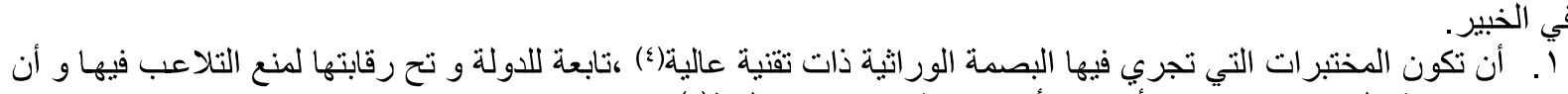

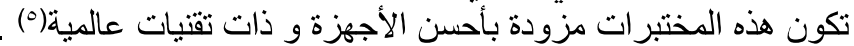

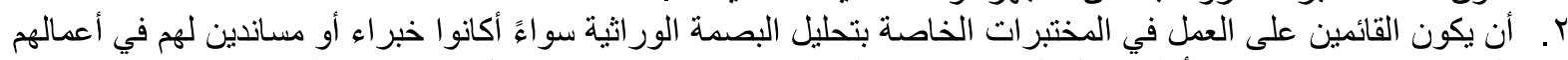

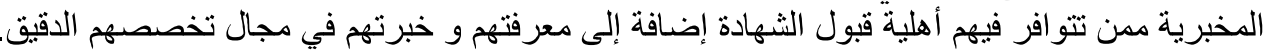

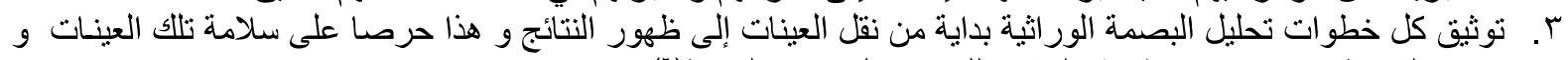

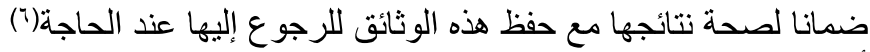

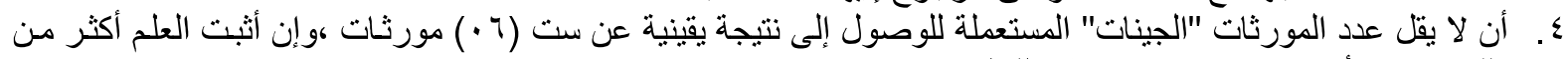

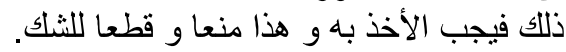

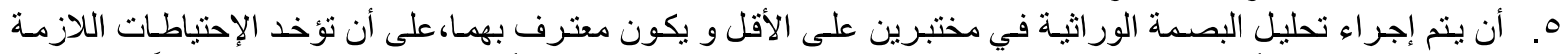

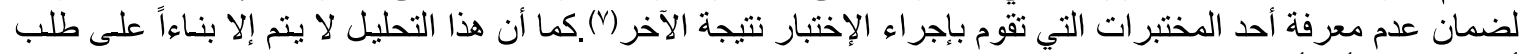

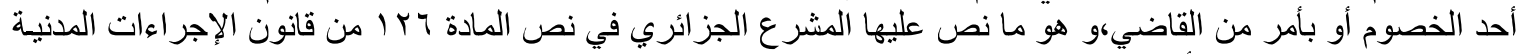

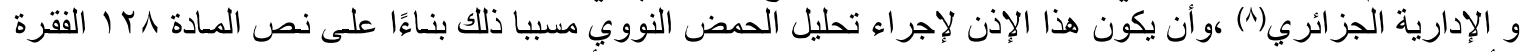

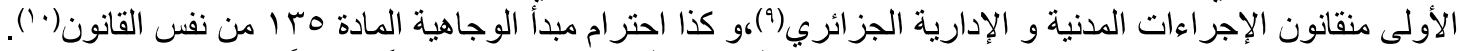

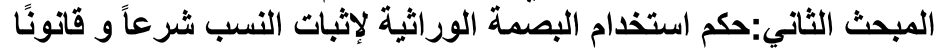

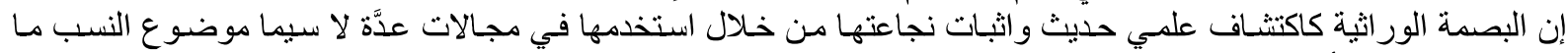

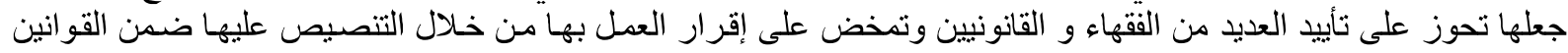
،لذا فما في حكم استخداها في اثبات النسب من الناحية الشر عية و القانونية؟

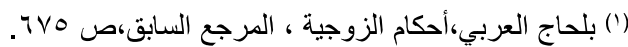

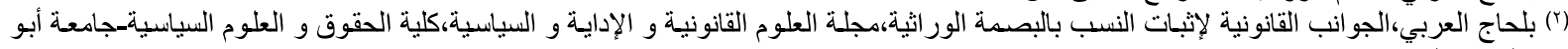

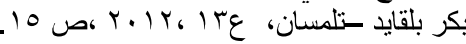

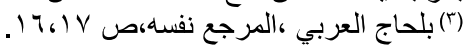

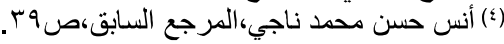

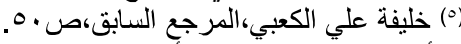

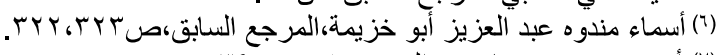

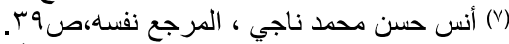

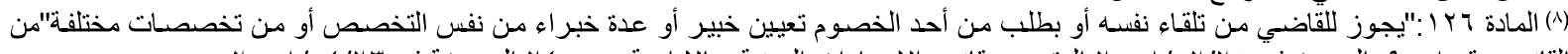

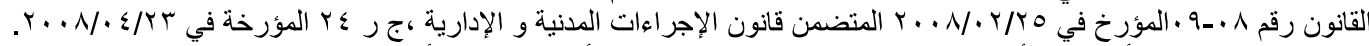

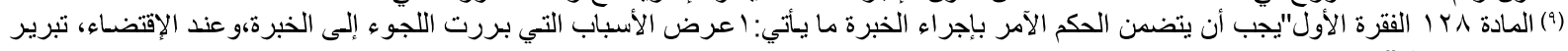

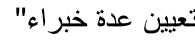

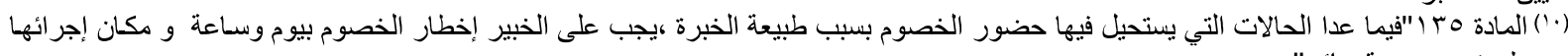
عن طريق محضر قضائي". 
أولا:حكم استخدام البصمة الوراثية لاثبات النسب شرعاً

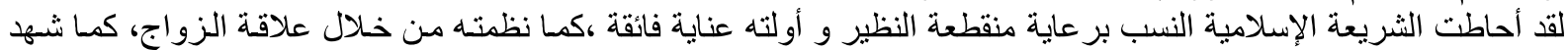

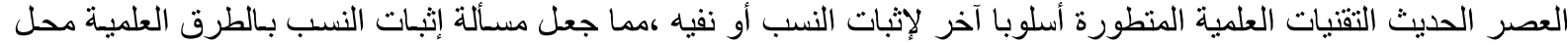

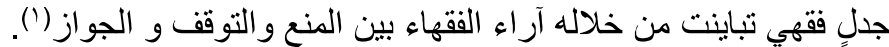

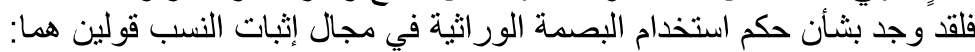

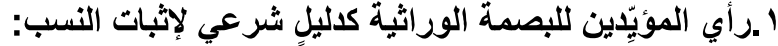

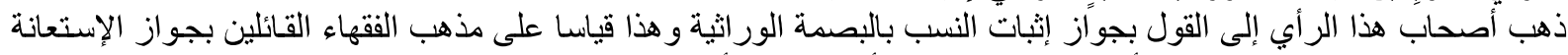

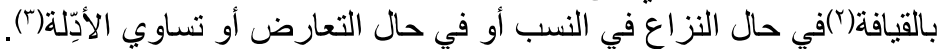

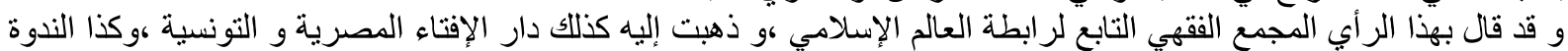

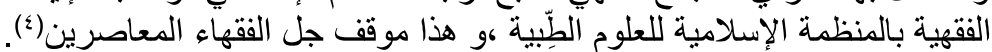

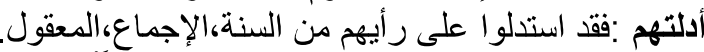

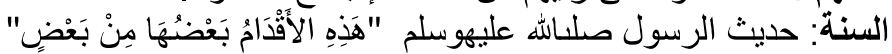

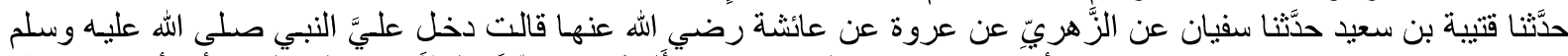

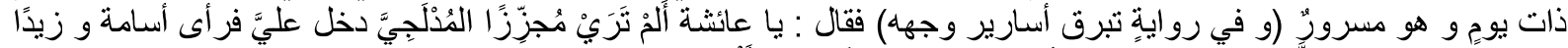

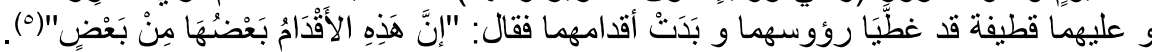

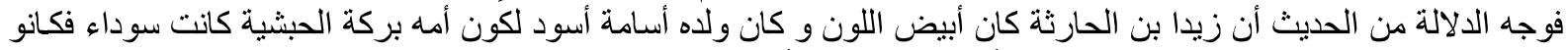

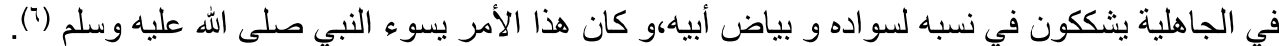

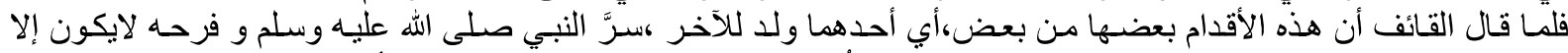

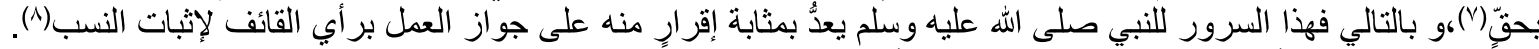

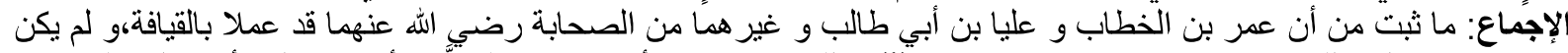

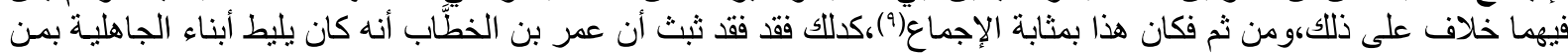

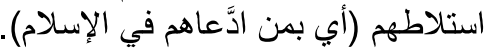

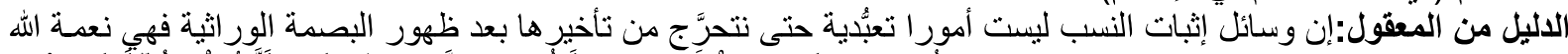

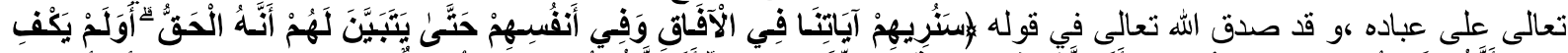

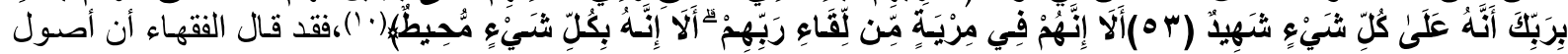

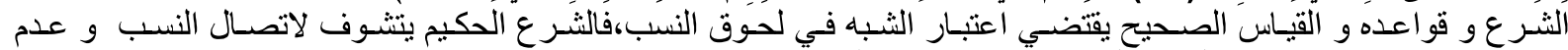

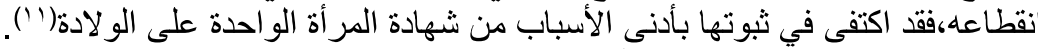

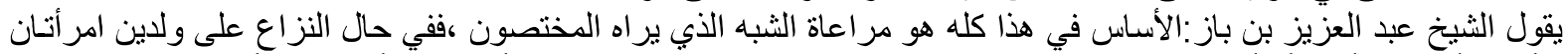

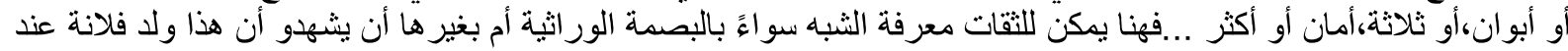

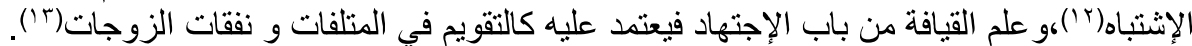

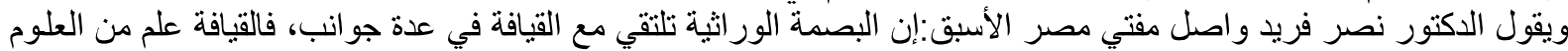

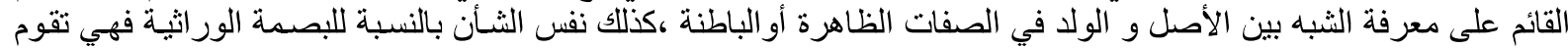

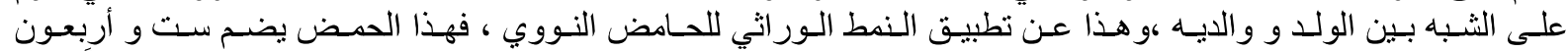

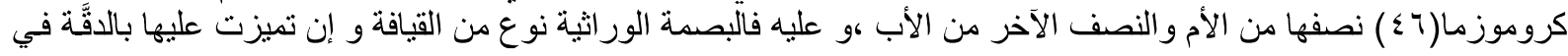

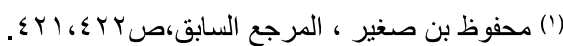

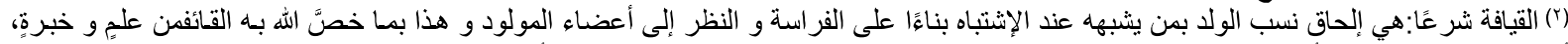

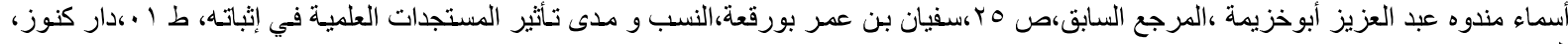

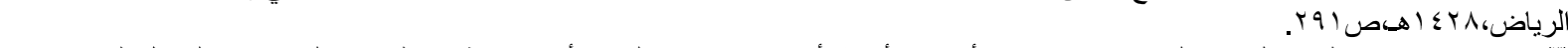

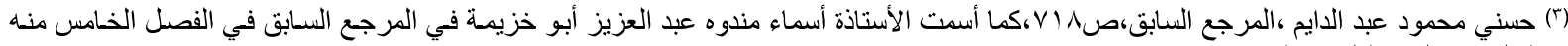

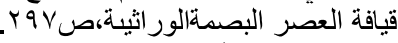

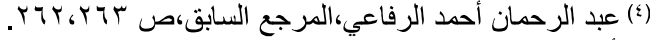

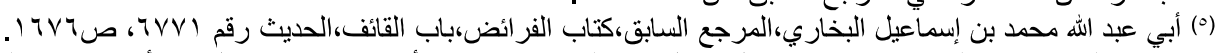

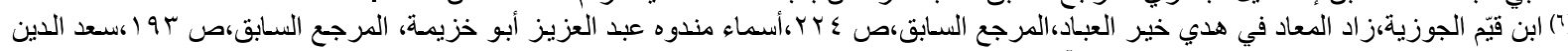

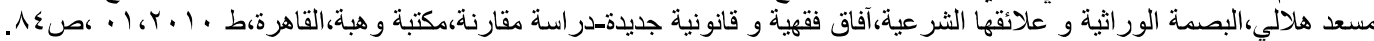

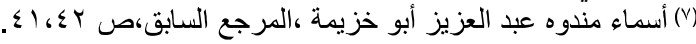

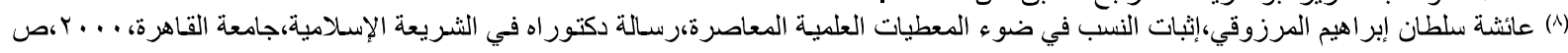

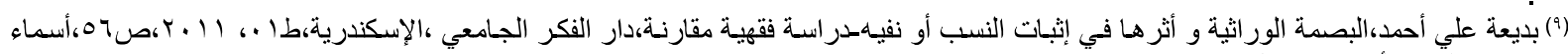

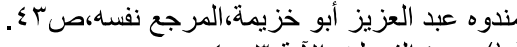

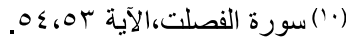

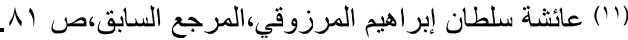

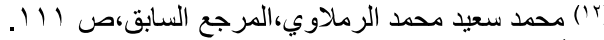

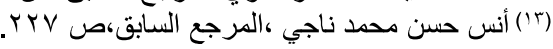




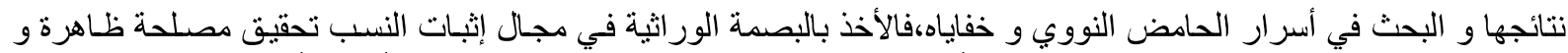

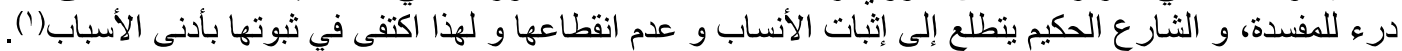

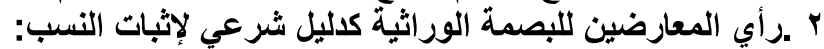

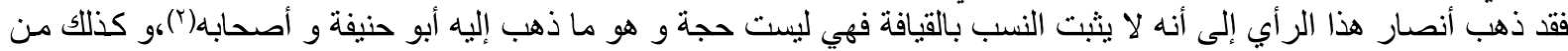

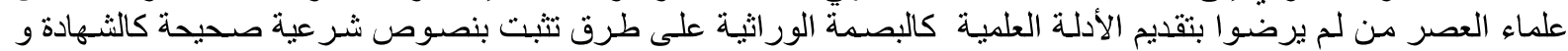

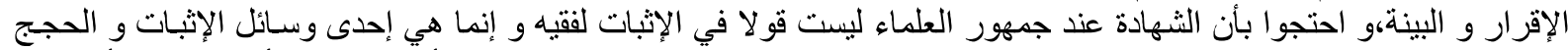

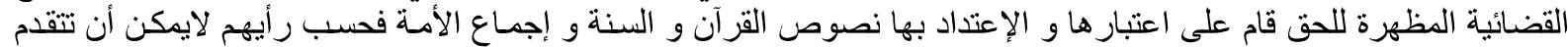

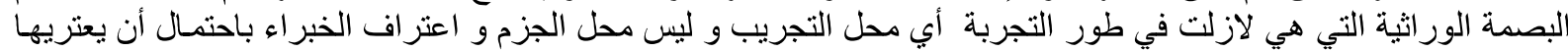

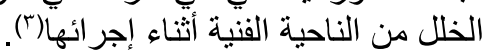
أدلتهم:استدلوا على رأيهم من الكتاب و الكناء السنة و الإجماع.

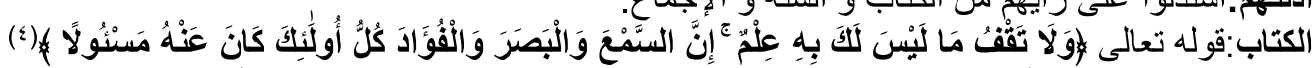

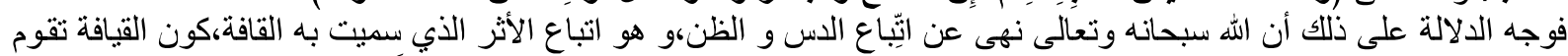

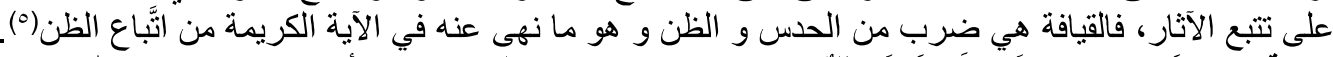

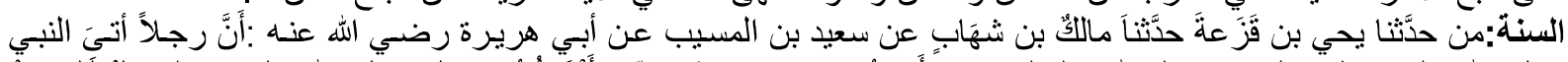

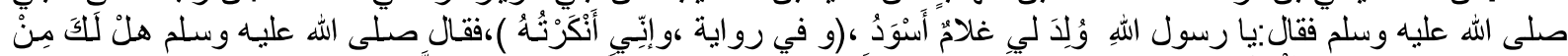

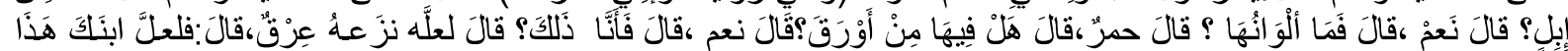

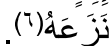

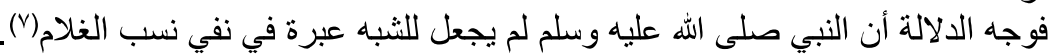

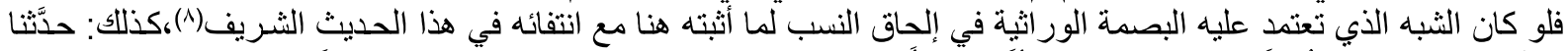

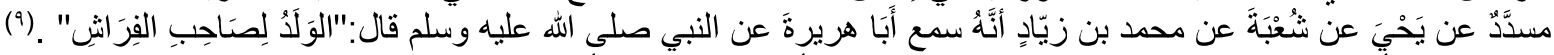

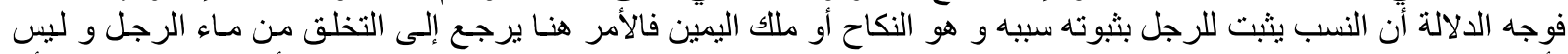

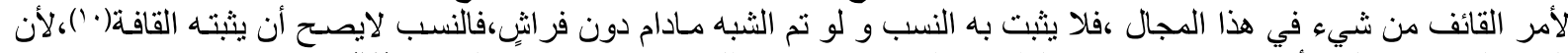

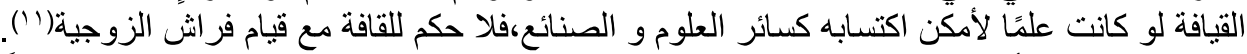

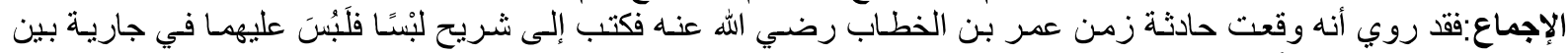

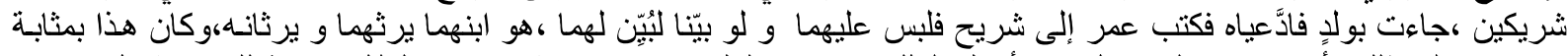

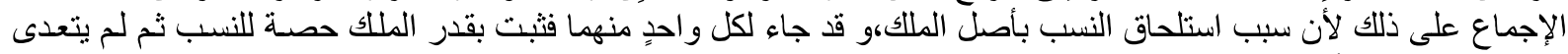

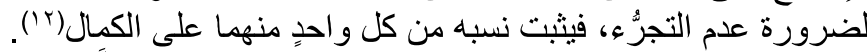

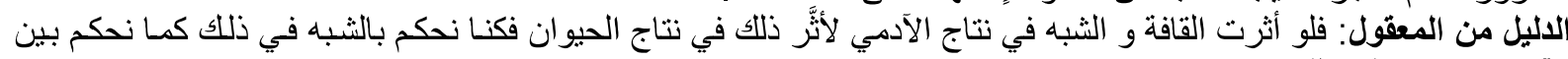

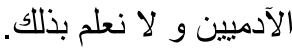

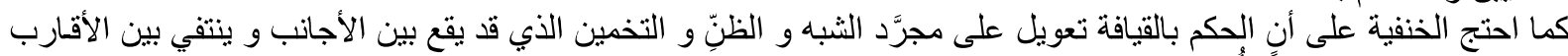

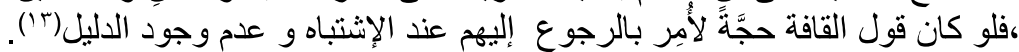

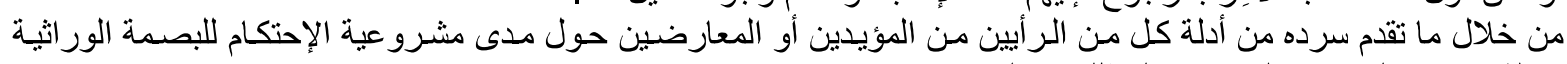

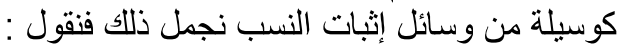

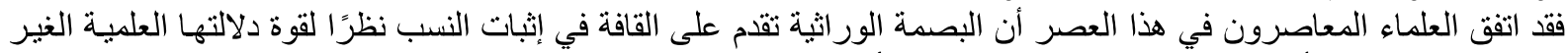

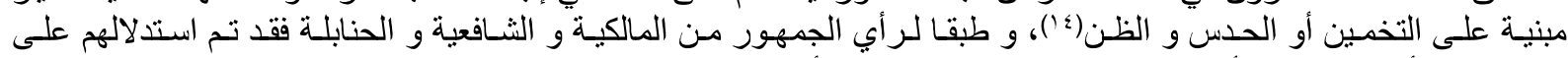

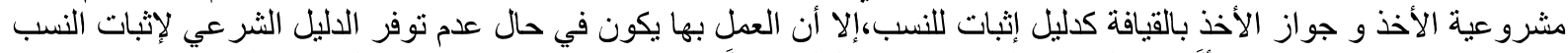

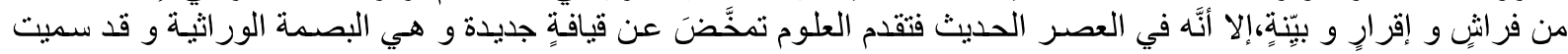

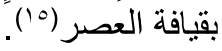

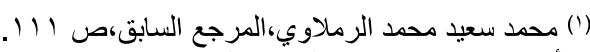

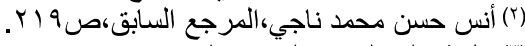

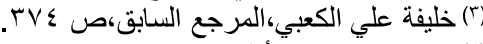

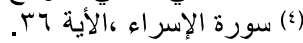

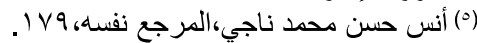

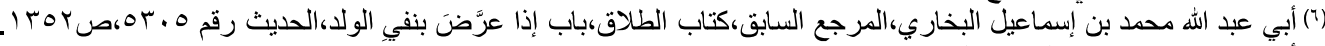

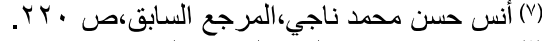

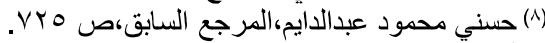

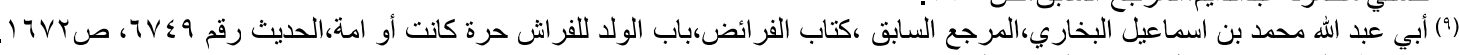

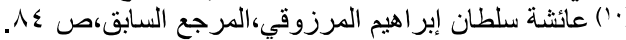

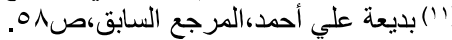

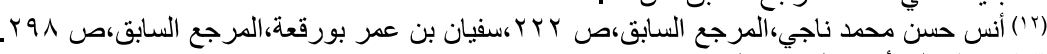
(1)

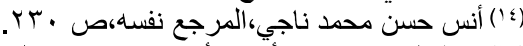

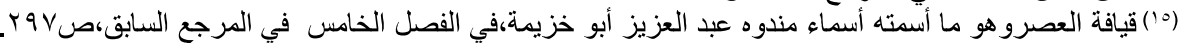




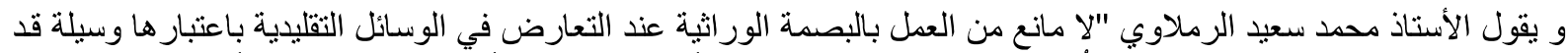

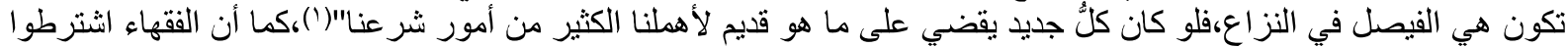

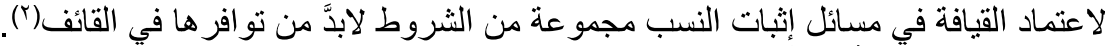

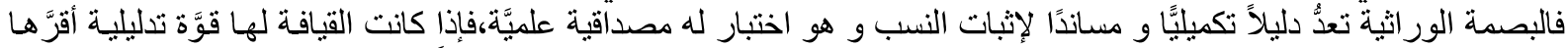

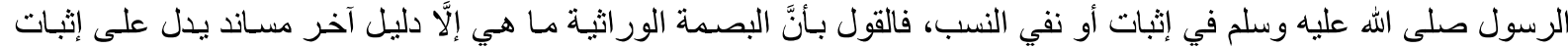

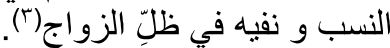

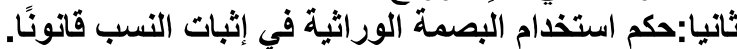

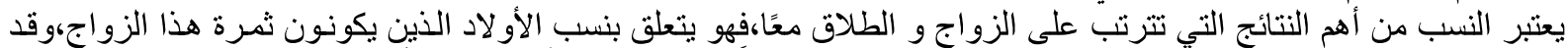

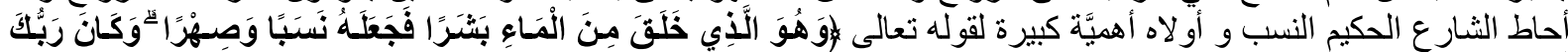

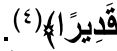

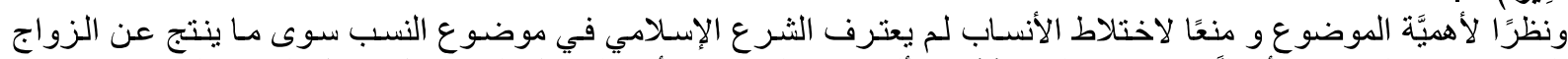

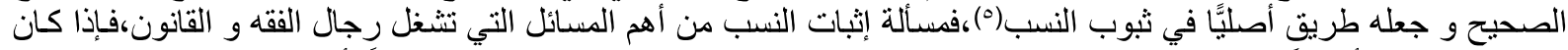

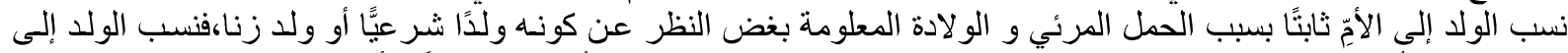

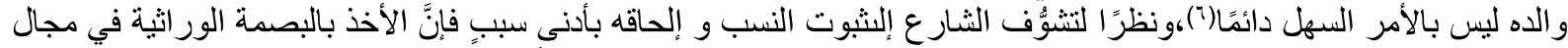

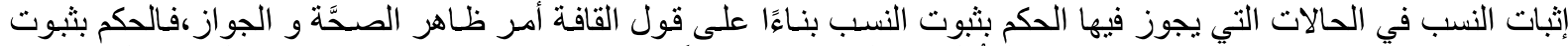

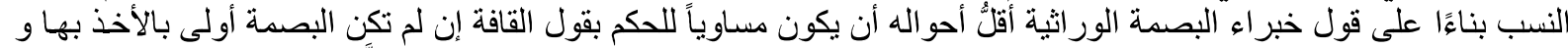

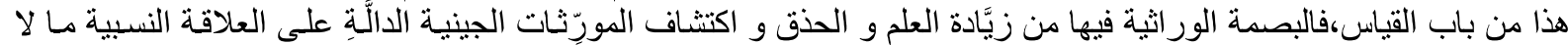

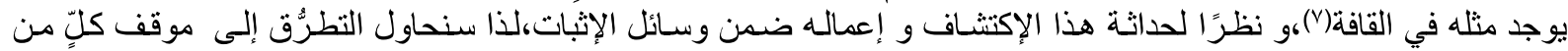

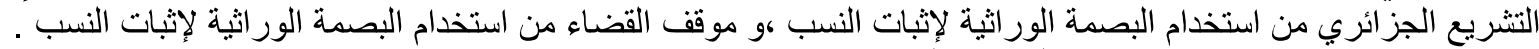

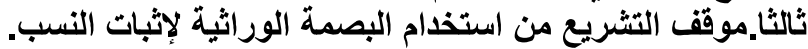

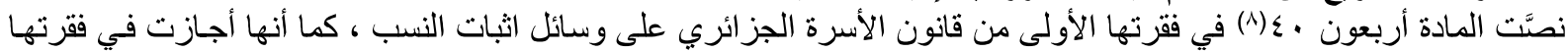

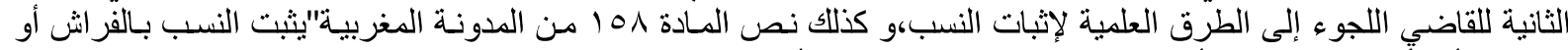

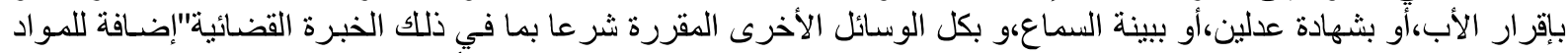

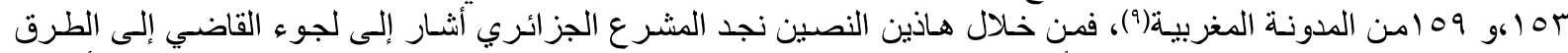

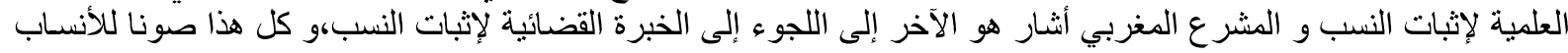

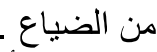

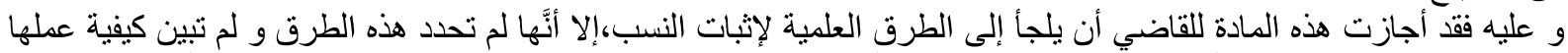

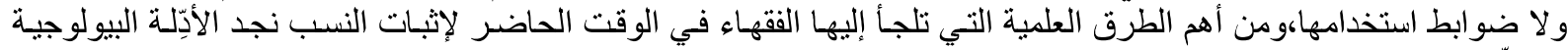

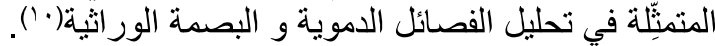
فنظرًا لحداثثة هذه التقنية و نظرًا لغياب نصوص الفيلئل القانون المنظمَّة لهذه المسألة، يمكن استخلاص من نص المادة مـ من ق أ ج ما

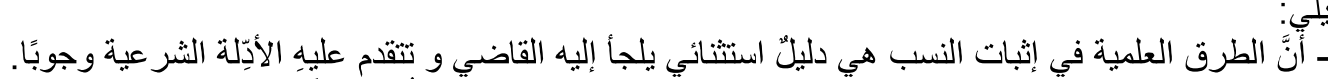

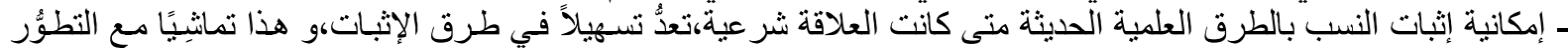
العلمي لوسائل الإثبات.

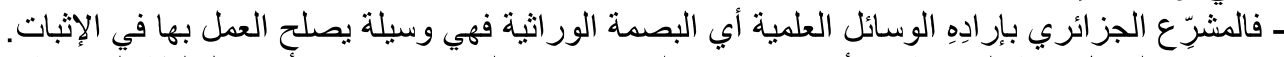

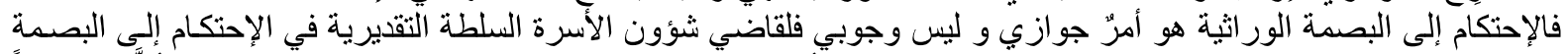

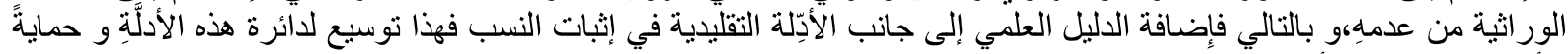
للأنساب و صون للأعر اض(')

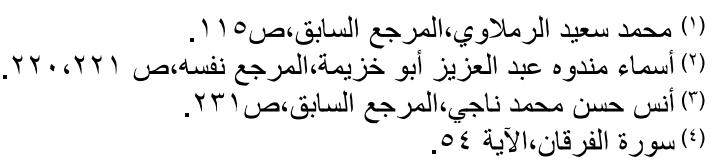

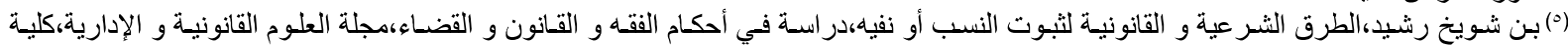

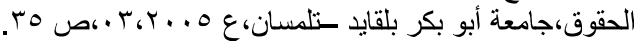

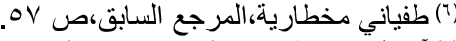

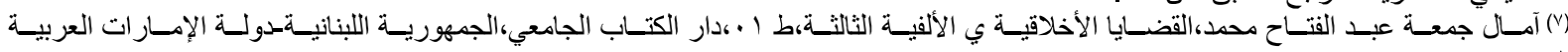

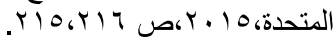

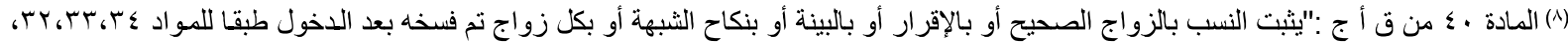

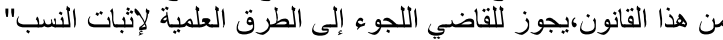

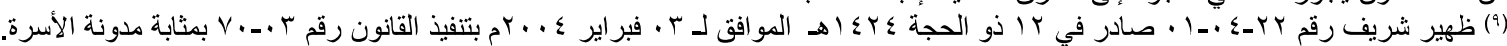

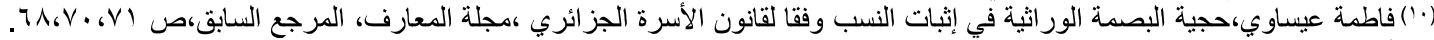

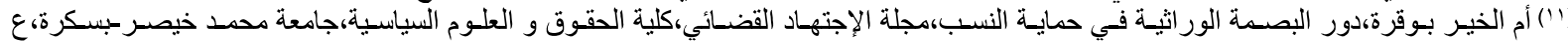

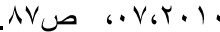




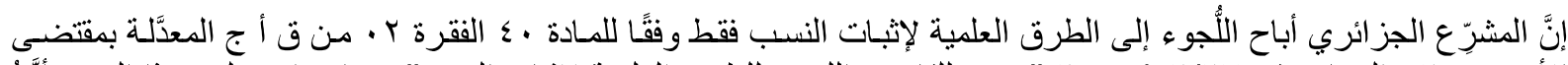

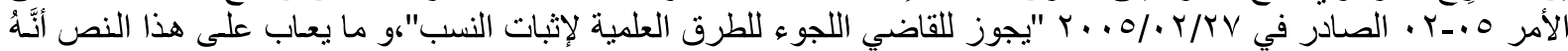

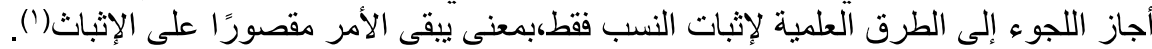

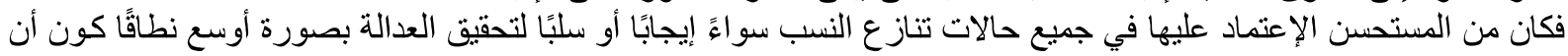

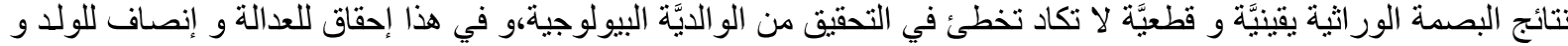

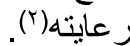

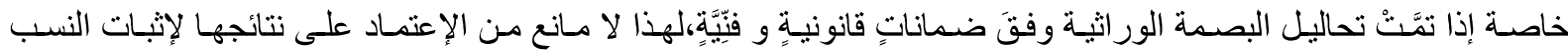

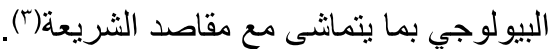

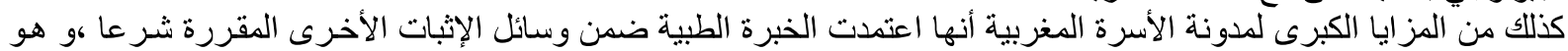

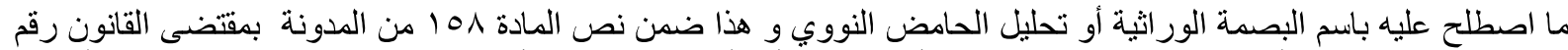

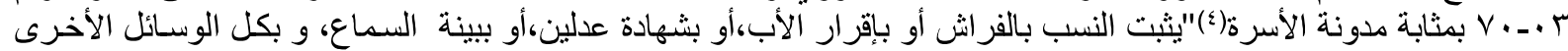

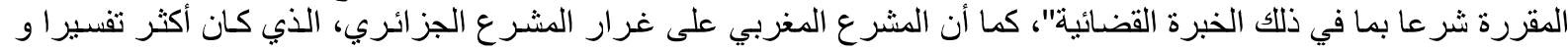

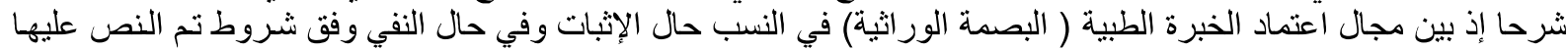

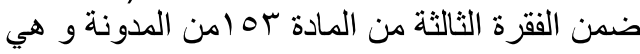

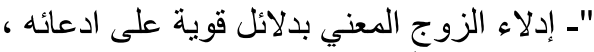

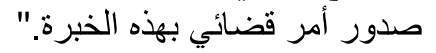

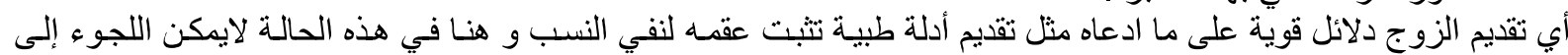

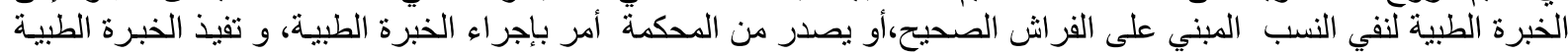

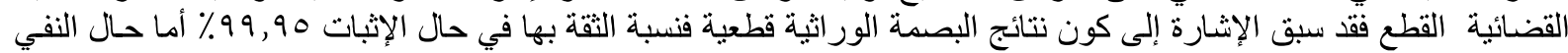

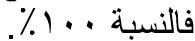

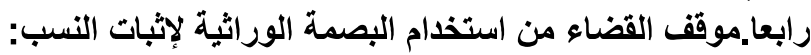

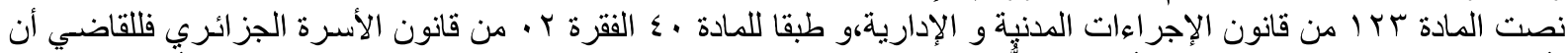

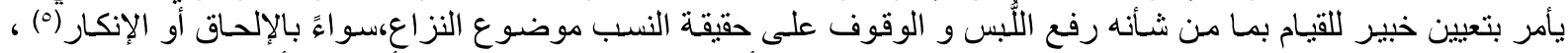

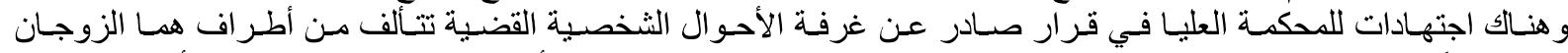

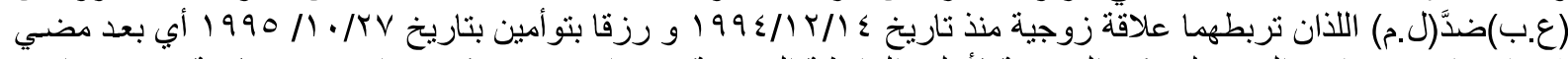

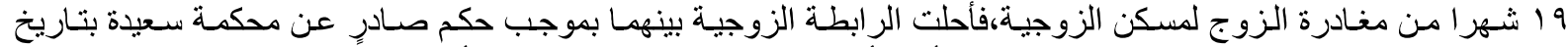

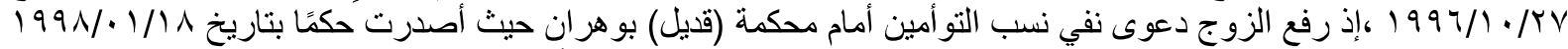

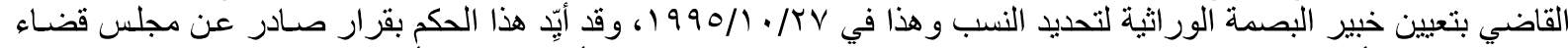

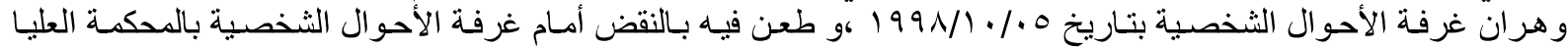

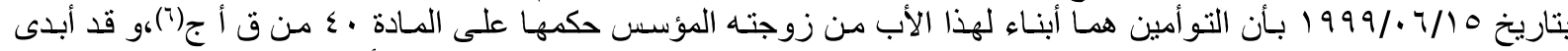

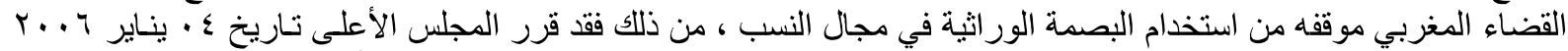

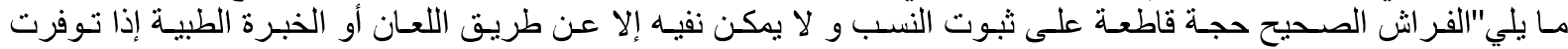

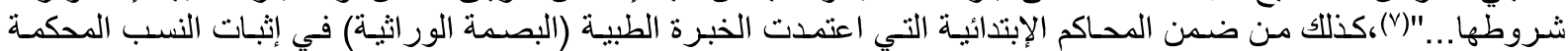

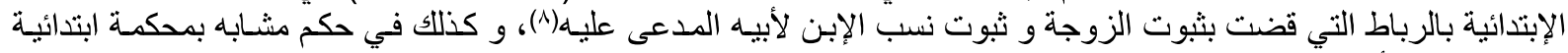

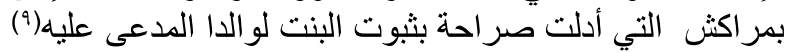

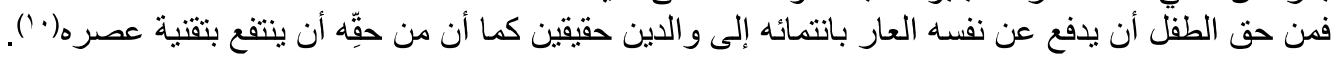

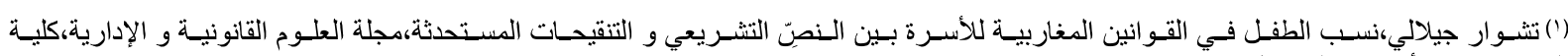

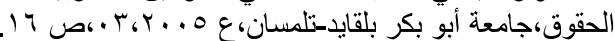

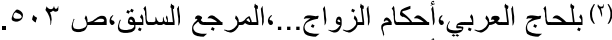

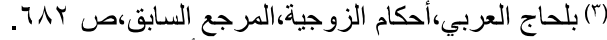

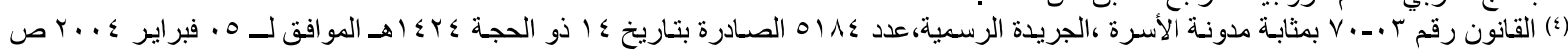

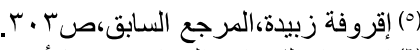

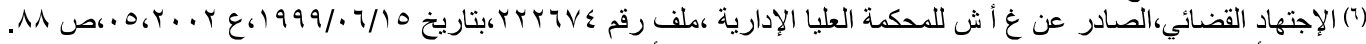

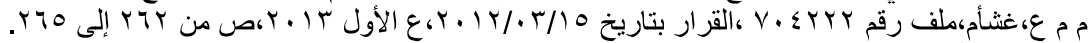

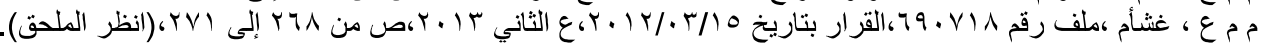

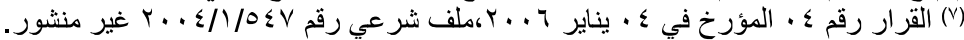

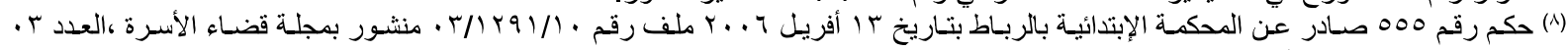

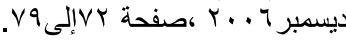

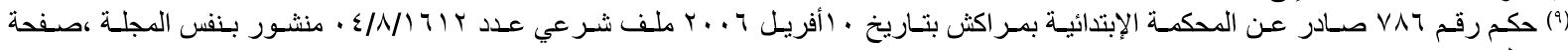
.

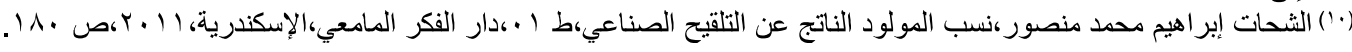




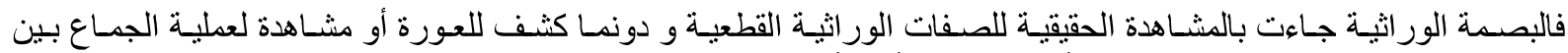

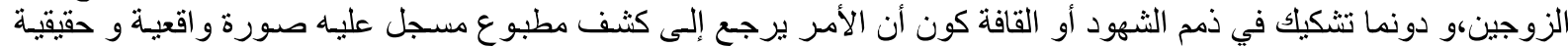

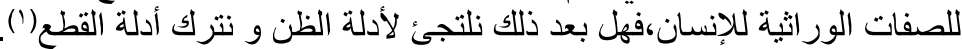

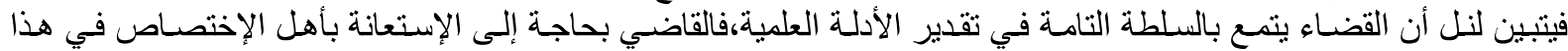

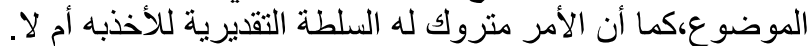

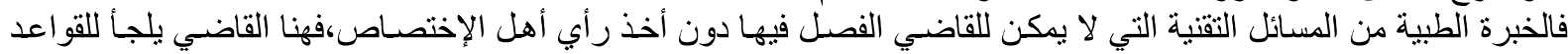

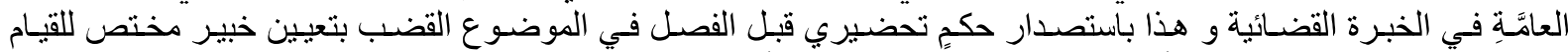

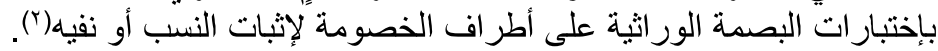
الخاتمة

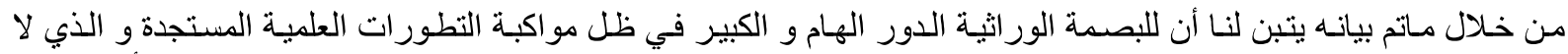

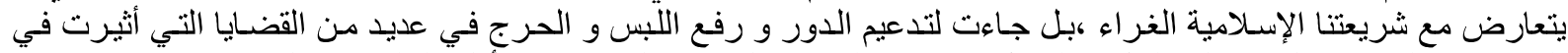

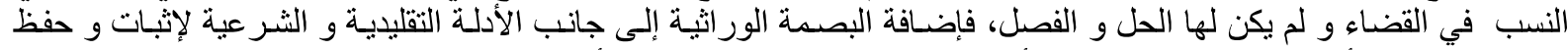

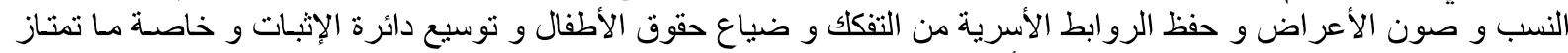

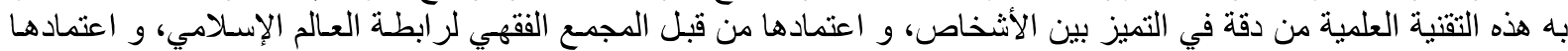

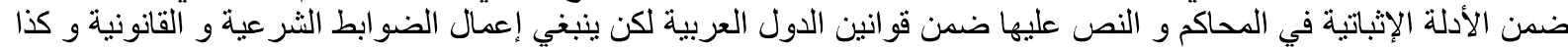
استعمال الردع و العقاب في حال التزوير و النتهالك حرمة الغير.
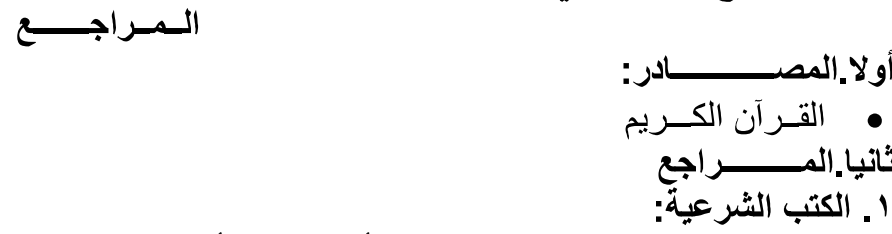

ا الإمام شمس الدين ابن عبد الله محمد بن أبي بكر بن أيوب ابن قيم الجوزيـة،الطرق الحكميـة في السياسـة الثرعية، دار الجيل

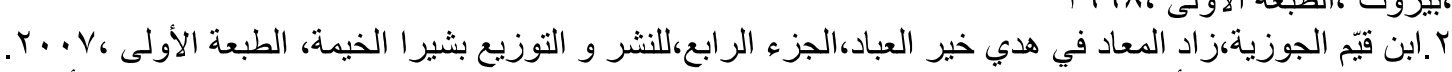

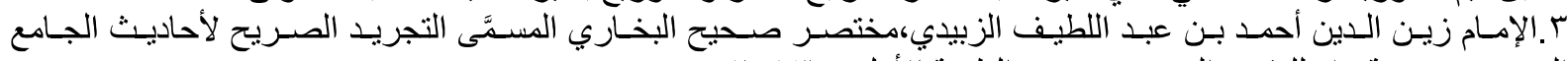

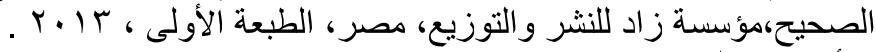

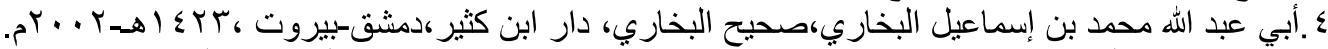

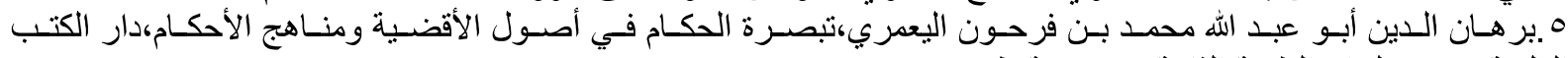

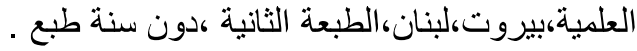

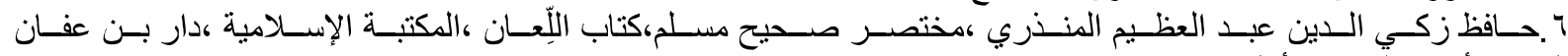

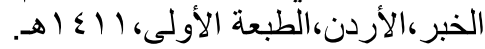

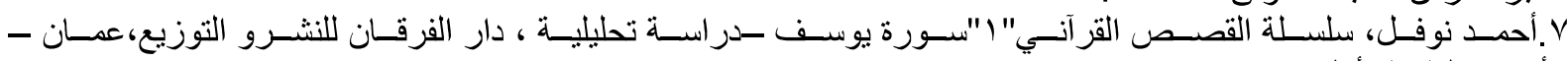

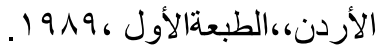

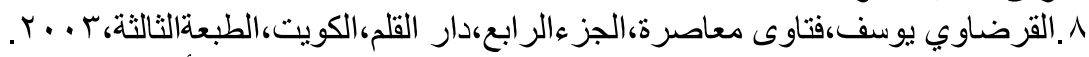

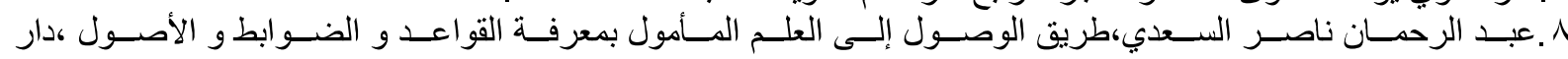

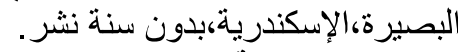

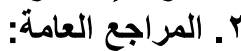

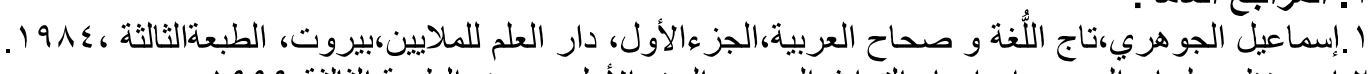

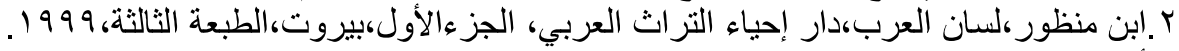

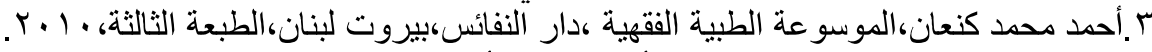

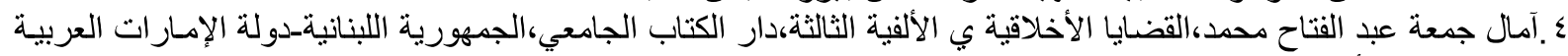

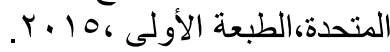

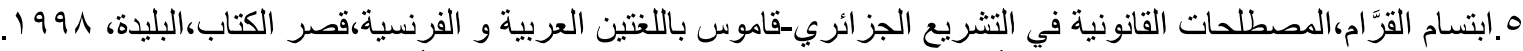

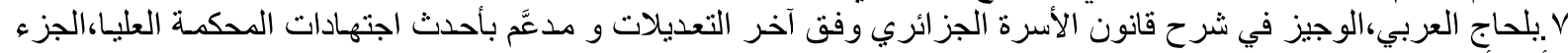

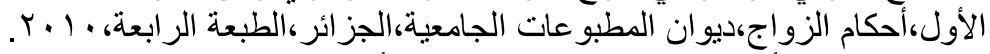

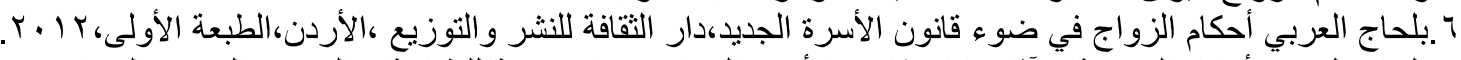

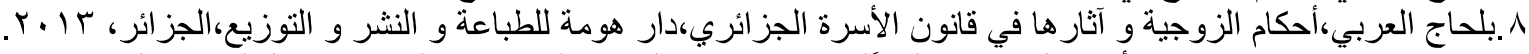

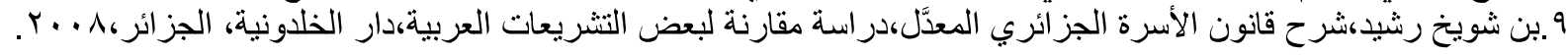

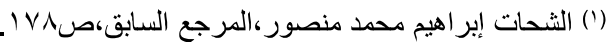

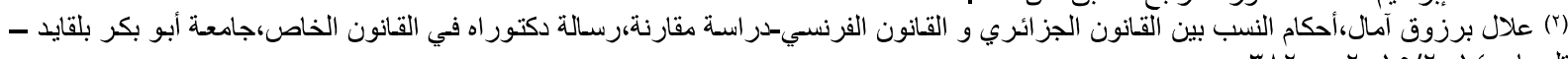

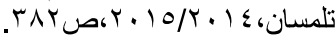




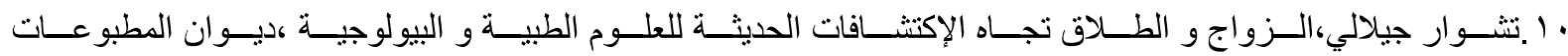

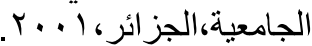

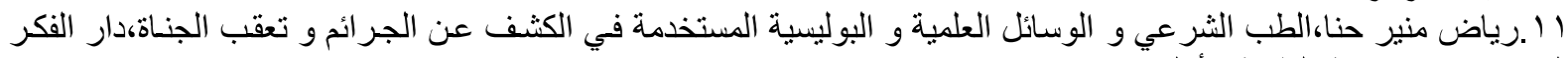

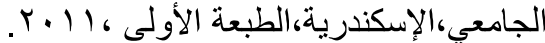

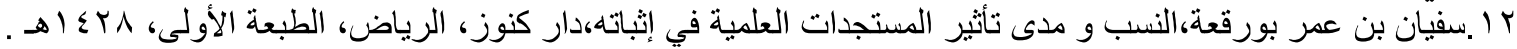

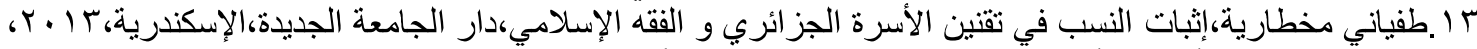

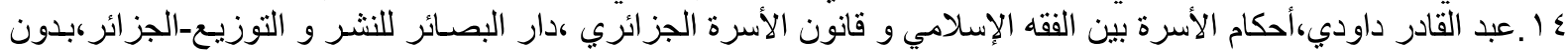

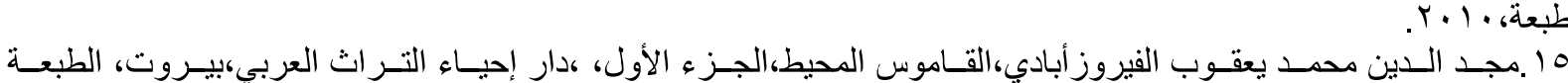

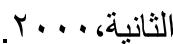

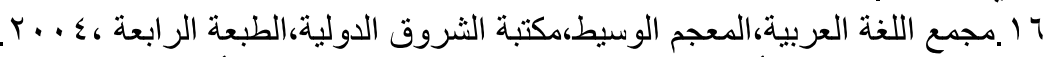

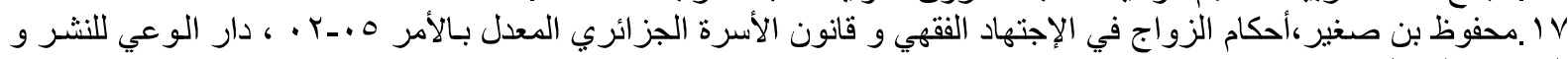

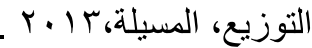

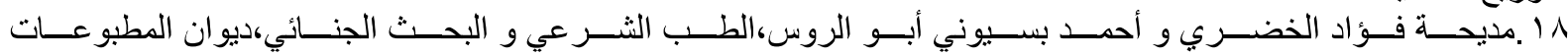

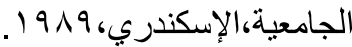

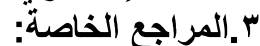

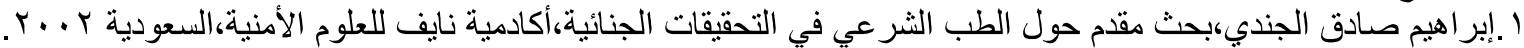

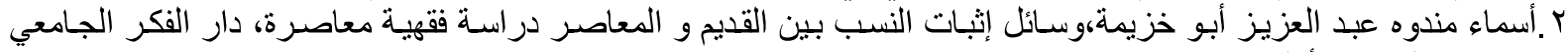

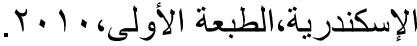

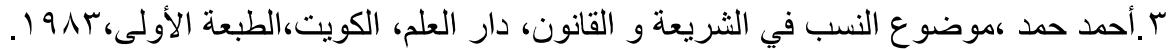

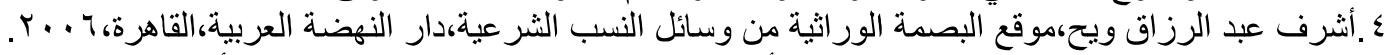

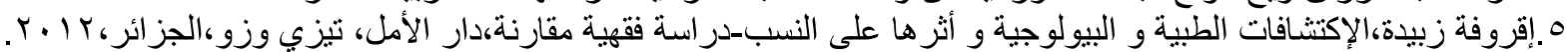

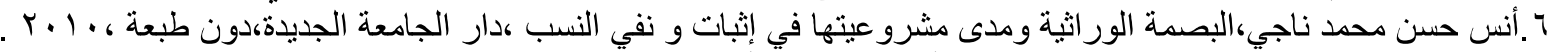

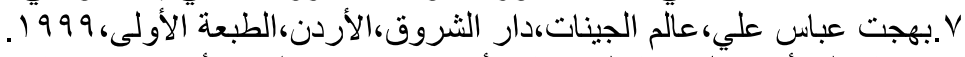

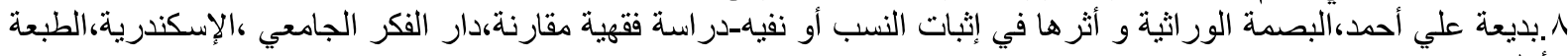

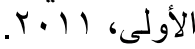

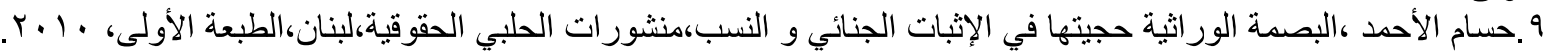

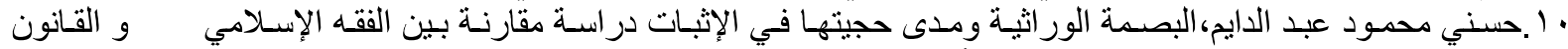

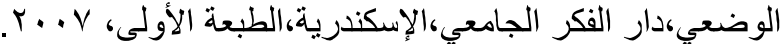

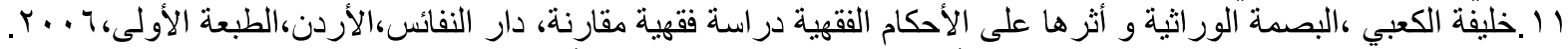

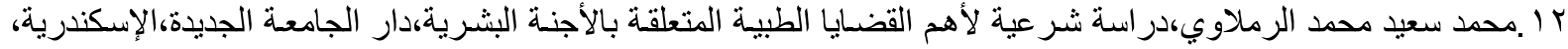
$r+14$

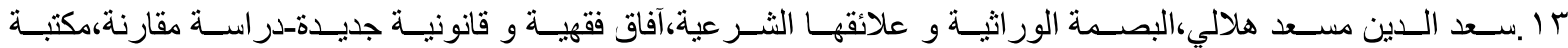

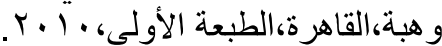

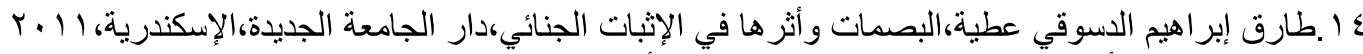

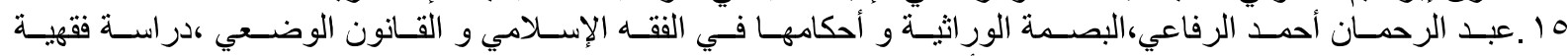

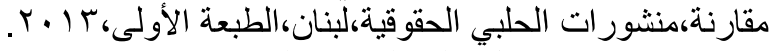

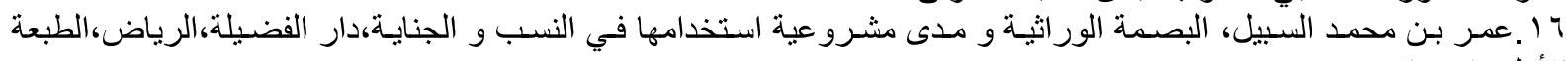

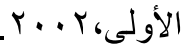

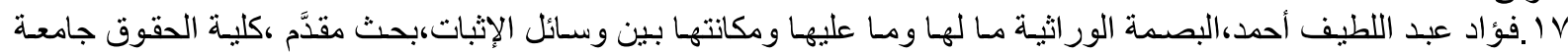

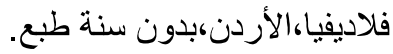

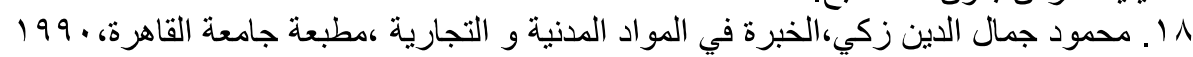
إنالثا.الرسائل و المذكرات العلمية:

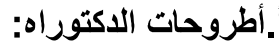

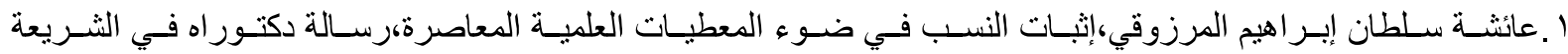

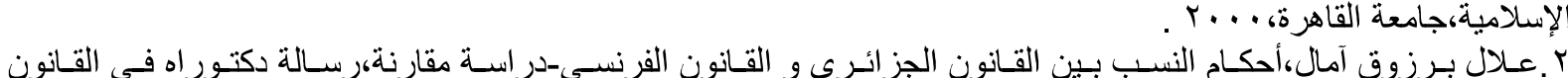

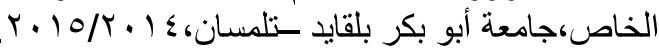

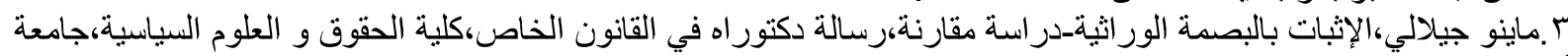




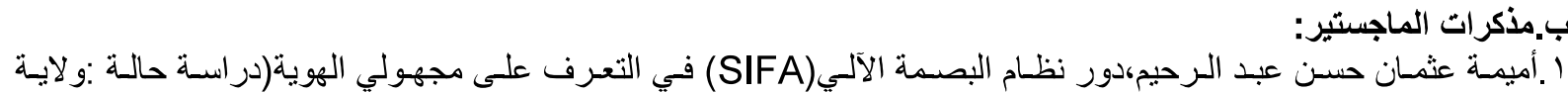
الخرطوم)،بحث لنيل الماجستير في علوم الأدلة الجنائية،جامعة الرباط الذوطني- كلية الدراسـات العليا و البحث العلمي،يناير $r+1 \mathrm{r}$ Y بوجلال علي،البصدة الور اثثية و أثرها على النسب،مذكرة ماجستير في القانون الطبي،كلية الحقوق و العلوم السياسية،جامعة

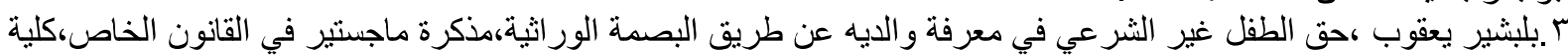

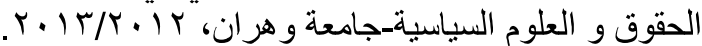

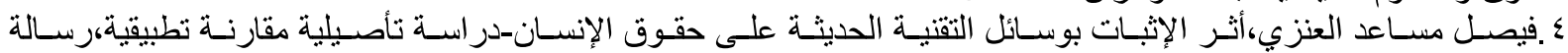

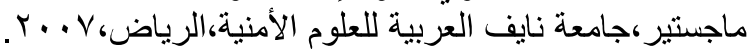

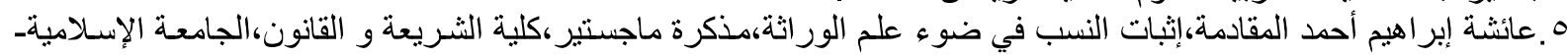

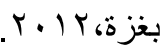

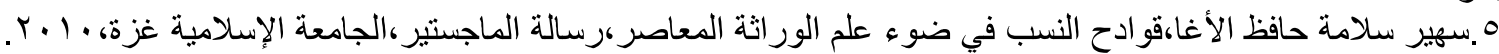

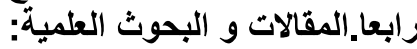

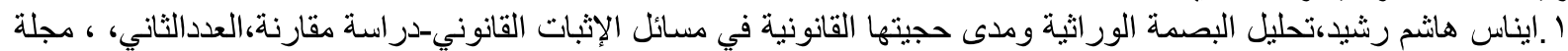

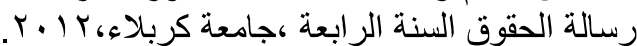

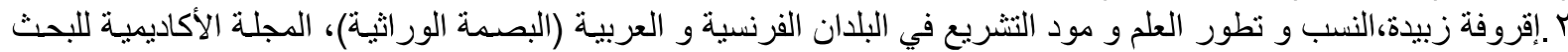

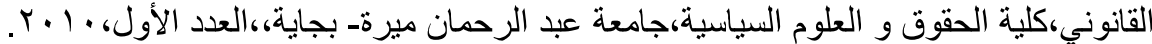

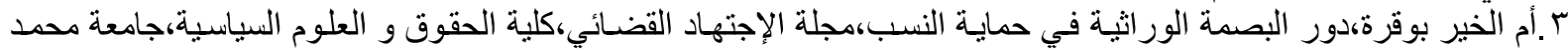

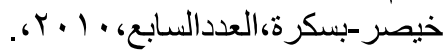

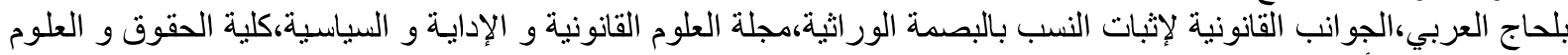

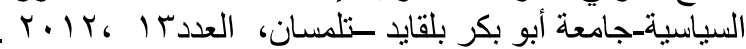

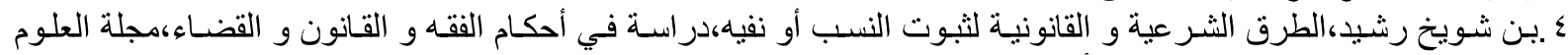

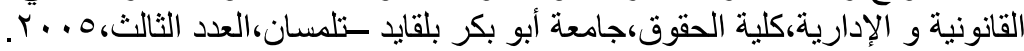

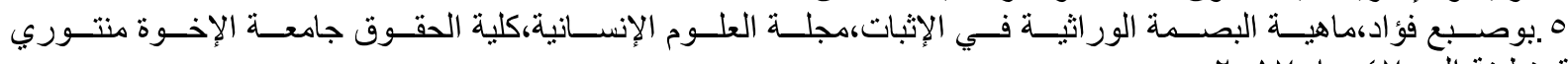

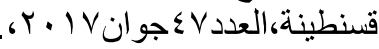

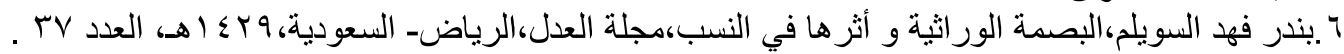

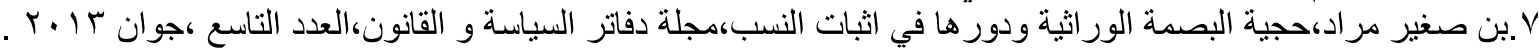

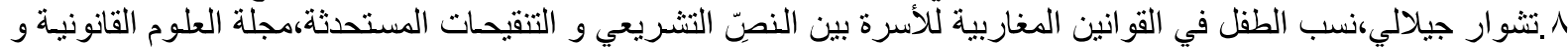

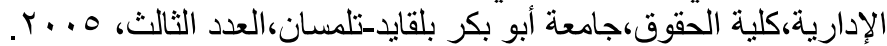

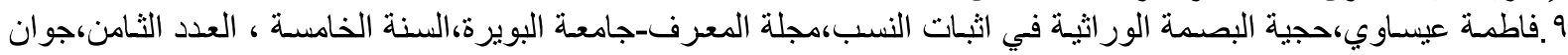
r. 1 .

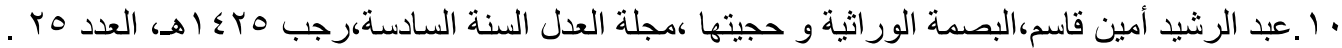

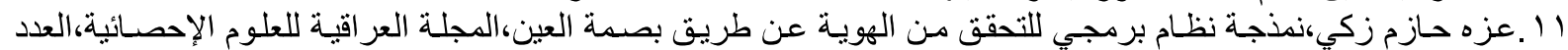

rtr.ti

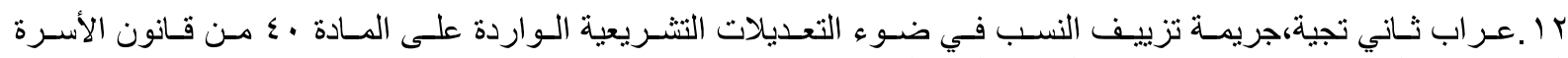

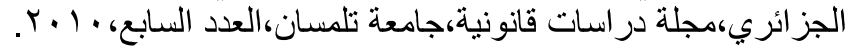

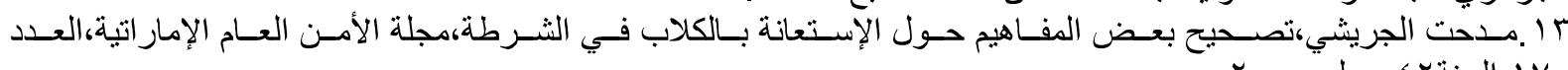

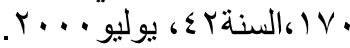

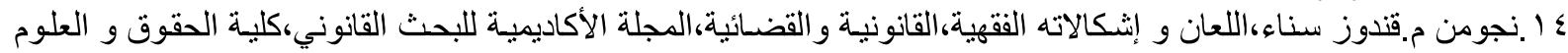

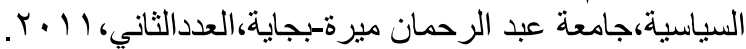

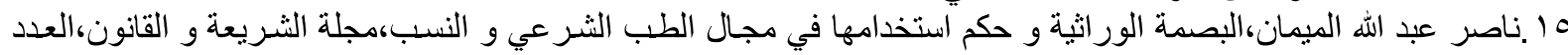

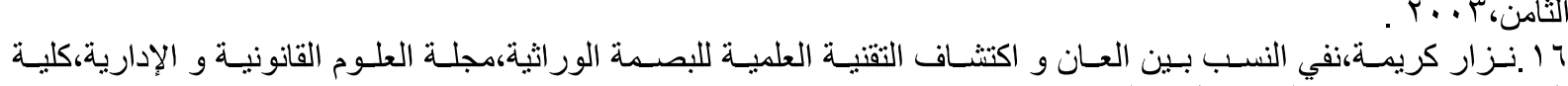

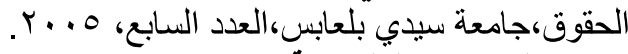
خامسا.النصوص التشريعية:

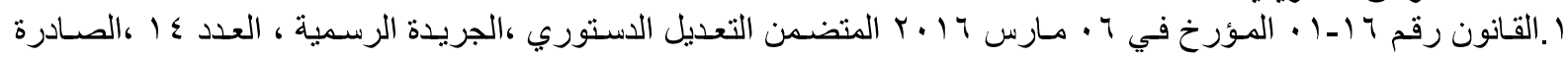

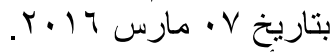

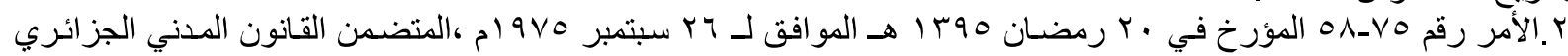

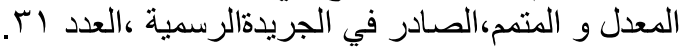

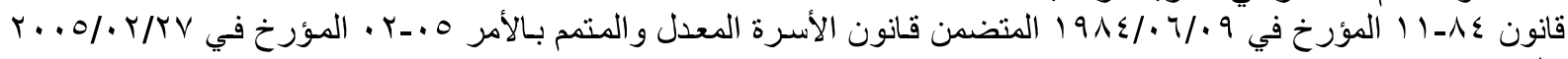




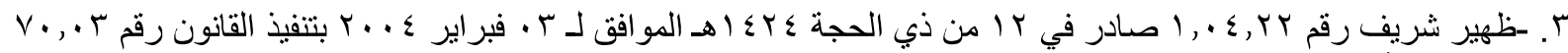
بمثابة مدونة الأسرة.

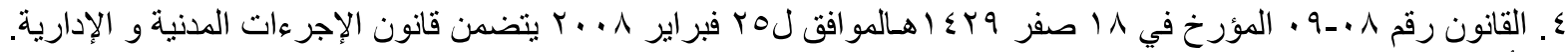

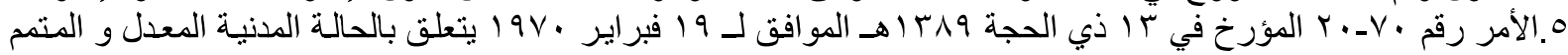

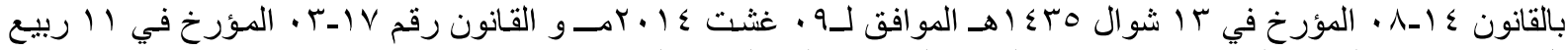

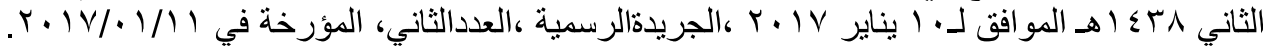

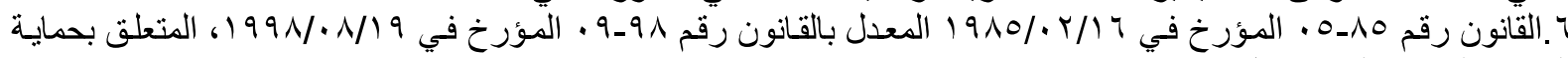

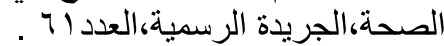

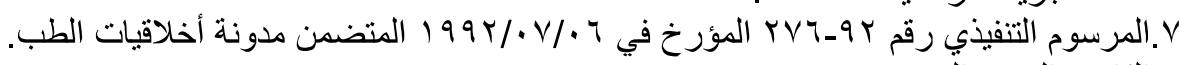

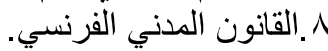

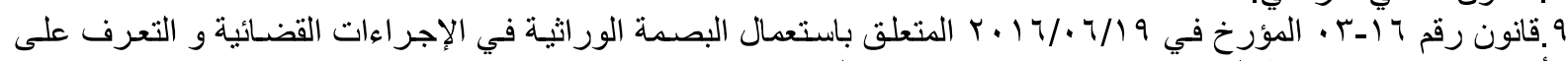

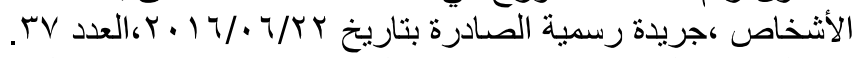

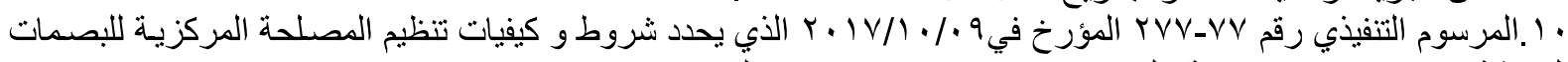

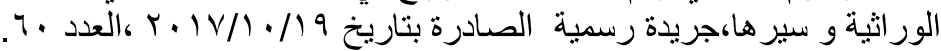

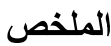

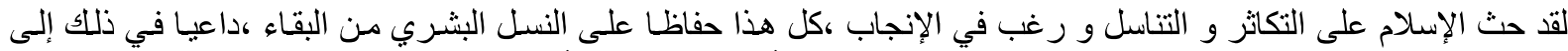

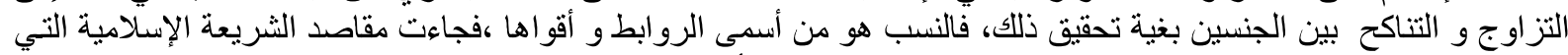

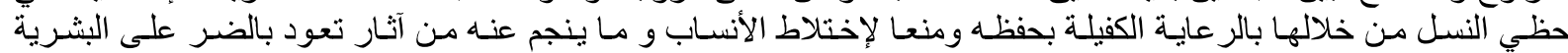

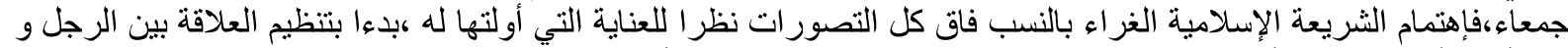

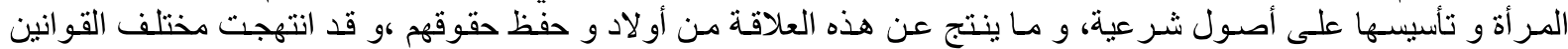

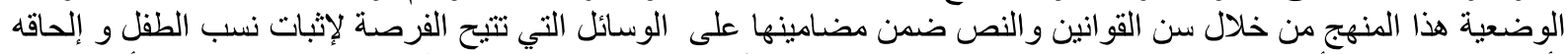

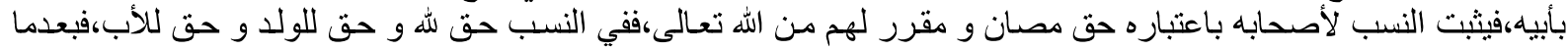

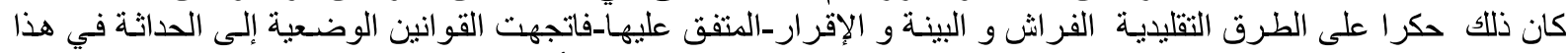

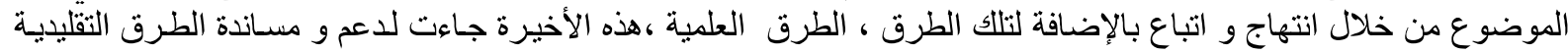

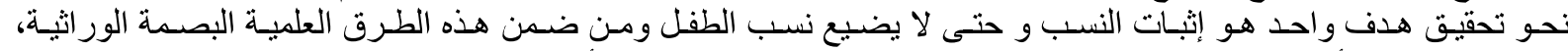

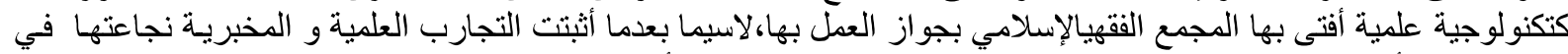

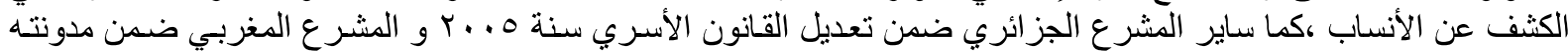

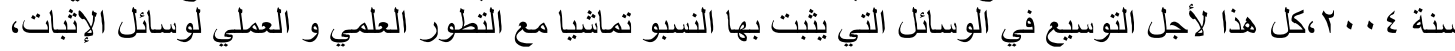

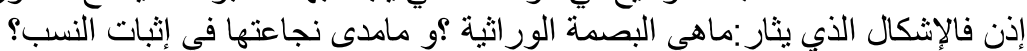

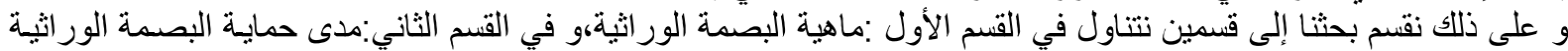

الكلمات المفتاحية: النسبـ البصمة الور اثية_الإثبات_الطرق العلمية-.

\section{Abstract}

Islam has urged reproduction and reproductive desire, all in order to protect the human offspring from survival, calling for intermarriage between the sexes in order to achieve this. Lineage is one of the highest and strongest ties.

So the forms that arise: What is the genetic footprint? How effective is it in proving lineage?

So we divide our research into two parts that we deal with in the first section: what is the genetic footprint, and in the second section: the extent to which the genetic fingerprint protects genealogies.

Keywords: ratio - genetic footprint - proof - scientific methods. 